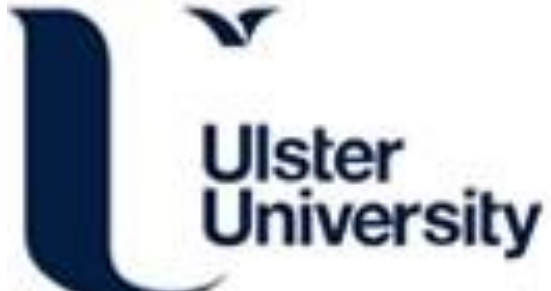

\section{Practitioner engagement by academic researchers: a scoping review of nursing, midwifery and therapy professions literature}

Daniels, N., Mackin (now Gillen), P., \& Casson, K. (Accepted/ln press). Practitioner engagement by academic researchers: a scoping review of nursing, midwifery and therapy professions literature. Research and Theory for Nursing Practice.

Link to publication record in Ulster University Research Portal

Published in:

Research and Theory for Nursing Practice

Publication Status:

Accepted/In press: 27/07/2019

\section{Document Version}

Author Accepted version

\section{General rights}

Copyright for the publications made accessible via Ulster University's Research Portal is retained by the author(s) and / or other copyright owners and it is a condition of accessing these publications that users recognise and abide by the legal requirements associated with these rights.

\section{Take down policy}

The Research Portal is Ulster University's institutional repository that provides access to Ulster's research outputs. Every effort has been made to ensure that content in the Research Portal does not infringe any person's rights, or applicable UK laws. If you discover content in the Research Portal that you believe breaches copyright or violates any law, please contact pure-support@ulster.ac.uk. 


\section{Research and Theory for Nursing Practice \\ Practitioner engagement by academic researchers: a scoping review of nursing, midwifery and therapy professions literature \\ --Manuscript Draft--}

Manuscript Number:

Full Title:

Article Type:

Keywords:

Corresponding Author:
RTNP-D-18-00125R2

Practitioner engagement by academic researchers: a scoping review of nursing, midwifery and therapy professions literature

\section{Research Study}

research; practitioner engagement; research practice gap; scoping review

Nicola Daniels, MAEd, BSc(Hons)

University of Ulster

Belfast, Northern Ireland UNITED KINGDOM

Corresponding Author Secondary Information:

Corresponding Author's Institution:

University of Ulster

Corresponding Author's Secondary Institution:

First Author: Nicola Daniels, MAEd, BSc(Hons)

First Author Secondary Information:

Order of Authors (with Contributor Roles): Nicola Daniels, MAEd, BSc(Hons) (Conceptualization; Data curation; Formal analysis; Investigation; Methodology; Project administration; Resources; Software; Writing original draft)

Patricia Gillen, PhD, MSc, PGD, BSc, RM, RGN, FHEA (Conceptualization; Funding acquisition; Supervision; Validation; Writing - review \& editing)

Karen Casson, PhD (Conceptualization; Funding acquisition; Supervision; Validation; Writing - review \& editing)

Order of Authors:

Nicola Daniels, MAEd, BSc(Hons)

Patricia Gillen, PhD, MSc, PGD, BSc, RM, RGN, FHEA

Karen Casson, $\mathrm{PhD}$

Order of Authors Secondary Information:

Abstract:

Background: Engagement of frontline practitioners by academic researchers in the research process is believed to afford benefits towards closing the research practice gap. However, little is known about if and how academic researchers engage nurses, midwives or therapists in research activities or if evidence supports these claims of positive impact.

Method: A scoping review was undertaken using the Arksey and O'Malley (2005) framework to identify the extent to which this phenomenon has been considered in the literature.

Results: An iterative search carried out in CINAHL, Pubmed, Medline and Embase retrieved 32 relevant papers published 2000 to 2017, with the majority from the last two-years. Retained papers described or evaluated active engagement of a practitioner from nursing, midwifery and therapy disciplines in at least one stage of a research project other than as a study participant. Engagement most often took place in one research activity with few examples of engagement throughout the research process. Limited use of theory and variations in terms used to describe practitioner engagement by researchers was observed. Subjective perspectives of practitioners' experiences and a focus on challenges and benefits were the most prominently reported outcomes. Few attempts were found to establish effects which could support claims that practitioner engagement can enhance the use of findings or impact health outcomes. 
Conclusion: It is recommended that a culture of practitioner engagement is cultivated by developing guiding theory, establishing consistent terminology and building an evidence base through empirical evaluations which provide objective data to support claims that this activity can positively influence the research practice gap.

Additional Information:

Question

Response

Please confirm you have approval from all Yes

Co-authors to submit this manuscript.

I represent and warrant that I am

authorized to execute this transfer of copyright on behalf of all the authors of this article.

The undersigned author(s) warrants and Agree

represents that the article is original, is not under consideration by another journal, has not been published previously, and contains no matter that is libelous, unlawful, or that infringes upon another copyright.

All individuals who contributed are listed. Yes

I confirm that the contribution contains no Confirmed libelous or unlawful statements, does not infringe upon the rights or the privacy of others, and does not contain any material or instructions that might cause harm or injury.

The undersigned author(s) transfers all copyright ownership of the article to the Journal, in the event that the article is accepted and published. In the event that the paper is rejected or withdrawn, the rights revert back to the author. This transfer of copyright includes, but is not limited to, the worldwide rights to any and all forms of publication now known or hereafter developed, including all forms of print and electronic media. NOTE: If you have Open Access requirements please contact us should your paper be accepted regarding our SPC Open option.

Please confirm you own or have been Yes - I agree to transfer all copyright ownership of the article to the Journal in the event that it is accepted and published.

\section{Yes}

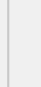


Please confirm that no author has a conflict of interest. A potential conflict of interest would arise if one or more of the authors of a paper also have a financial interest or relationship (or a close relative with such an interest) in a company or commercial product that might benefit from the paper's publication. In such cases, disclosure is important.
Yes - I/we (all authors) have no potential conflicts of interest related to the submitted paper. 
Title: Practitioner engagement by academic researchers: a scoping review of nursing, midwifery and therapy professions literature

Running head: Practitioner engagement by academic researchers

Author information: Nicola Daniels, MAEd, BSC(Hons), MBAOT, FHEA

School of Nursing, Faculty of Life and Health Sciences, Ulster University

Patricia Gillen, PhD, MSc, PGD, BSc, RM, RGN, FHEA

Southern Health and Social Care Trust and School of Nursing, Faculty of Life and Health Sciences, Ulster University

Karen Casson, $\mathrm{PhD}$,

School of Nursing, Faculty of Life and Health Sciences, Ulster University

Corresponding author: Nicola Daniels

Address: School of Nursing, Ulster University, Shore Road, Newtownabbey, Northern Ireland BT37 0QB Telephone: (44) 02870123456 email: Daniels-n@ulster.ac.uk

\section{Statement of author roles/contributions to the manuscript.}

All persons who meet authorship criteria are listed as authors. All authors certify that they have participated sufficiently in the work to meet the four criteria recommended by the ICMJE.

As principal investigator Nicola Daniels led the design and conduct of the review and took lead responsibility for the collection, analysis and interpretation of the literature. Nicola completed the first draft of this article and worked collaboratively with both other authors to produce the final version.

Patricia Gillen and Karen Casson conceived the original project idea and secured funding for this study. Both supervised and contributed to the design of the review and its conduct including an active role in the assessment of included papers. Both had a substantial role in revising the draft of this work and contributing to iterative development to the final version through critical review and contribution of knowledge.

All authors have approved the final version submitted for publication. 
Nicola Daniels

PhD Researcher

School of Nursing

Ulster University

$26^{\text {th }}$ July, 2019

Dear Dr. Monsivais,

We submit a revised version of our manuscript, "Practitioner engagement by academic researchers: a scoping review of nursing, midwifery and therapy professions literature" with the further suggestions made by the reviewer now added to our work. We hope that we have satisfactorily addressed the points made by the reviewer and have detailed how these have been addressed in a response.

As outlined in our initial covering letter, we reiterate that all authors have contributed to the manuscript based on the International Committee of Medical Journal Editors criteria and all have read and approved this revised manuscript. This work is original and has not been submitted to any other publication. There are also no conflicts of interest to declare.

Thank you again for your consideration of this manuscript and we look forward to hearing from you in due course,

Yours Sincerely,

Nikki Daniels

Dr. Patricia Gillen, Dr. Karen Casson

Ulster University 
Dear Reviewer,

Thank you for taking time to review this revised submission. We are pleased that most of our responses have addressed the issues outlined in the initial review and that you feel the manuscript has improved.

We have addressed any outstanding issues as detailed in the table below and highlighted these changes in blue text within the manuscript.

\begin{tabular}{|c|c|}
\hline Reviewer's comments & Authors' responses \\
\hline $\begin{array}{l}\text { A simple definition of a scoping review is } \\
\text { lacking and would be beneficial to the } \\
\text { readers. }\end{array}$ & $\begin{array}{l}\text { A definition has now been added to page } 5 \\
\text { of the manuscript }\end{array}$ \\
\hline $\begin{array}{l}\text { Adding an earlier description of the target } \\
\text { population by discipline rather than } \\
\text { specialty would also be beneficial to the } \\
\text { reader. }\end{array}$ & $\begin{array}{l}\text { On review of our work we recognise that } \\
\text { the title and background section repeatedly } \\
\text { refers to nurses, midwives and therapists as } \\
\text { the targeted disciplines, however the } \\
\text { abstract, concluding section of the } \\
\text { background and lead in to the method refer } \\
\text { more broadly to practitioners. To maintain } \\
\text { the clear focus of the review to these } \\
\text { disciplines, amendments have been made } \\
\text { to the abstract and specific reference to } \\
\text { these disciplines when setting out the } \\
\text { objectives of the review (page 4), when } \\
\text { defining the population (page } 6 \text { ) and in the } \\
\text { recommendations section of the review } \\
\text { (page 21). }\end{array}$ \\
\hline $\begin{array}{l}\text { It is suggested that the recommendations } \\
\text { include further research comparing what is } \\
\text { known in the distinct body of literature in } \\
\text { the health services research-practice } \\
\text { partnerships (campus-community } \\
\text { partnerships) and the findings presented } \\
\text { here. }\end{array}$ & $\begin{array}{l}\text { A recommendation has been added to the } \\
\text { conclusions and recommendations section } \\
\text { of the review (page 22). }\end{array}$ \\
\hline
\end{tabular}

We hope that the above additions have fulfilled the suggestions made.

Kind regards,

Nikki Daniels, Dr. Patricia Gillen, Dr. Karen Casson 
1. Practitioner engagement by academic researchers

\section{ABSTRACT}

Background: Engagement of frontline practitioners by academic researchers in the research process is believed to afford benefits towards closing the research practice gap. However, little is known about if and how academic researchers engage nurses, midwives or therapists in research activities or if evidence supports these claims of positive impact. Method: A scoping review was undertaken using the Arksey and O'Malley (2005) framework to identify the extent to which this phenomenon has been considered in the literature. Results: An iterative search carried out in CINAHL, Pubmed, Medline and Embase retrieved 32 relevant papers published 2000 to 2017, with the majority from the last two-years. Retained papers described or evaluated active engagement of a practitioner from nursing, midwifery and therapy disciplines in at least one stage of a research project other than as a study participant. Engagement most often took place in one research activity with few examples of engagement throughout the research process. Limited use of theory and variations in terms used to describe practitioner engagement by researchers was observed. Subjective perspectives of practitioners' experiences and a focus on challenges and benefits were the most prominently reported outcomes. Few attempts were found to establish effects which could support claims that practitioner engagement can enhance the use of findings or impact health outcomes. Conclusion: It is recommended that a culture of practitioner engagement is cultivated by developing guiding theory, establishing consistent terminology and building an evidence base through empirical evaluations which provide objective data to support claims that this activity can positively influence the research practice gap.

Key words: research, practitioner, engagement, research practice gap, scoping review 


\section{BACKGROUND}

Knowledge derived from research is a cornerstone of healthcare and evidence-based practice. Globally, there is a clear commitment and expectation that healthcare practices will be informed by the best available research evidence with the belief that this will result in optimal patient and health outcomes (Leach \& Tucker, 2018). Integration of research findings into practice is therefore embedded in the professional standards of nurses, midwives and therapists who deliver direct care worldwide. However, a plethora of literature documents the consistent and longstanding challenges that practitioners across these professions face in utilising research within their practice. In 1991, challenges were categorised as relating to the adopter, the organisation, the quality of the research, its presentation and accessibility (Funk, Champagne, Wiese, \& Tornquist, 1991). Nearly 30 years on, these challenges remain as recent literature continues to report barriers consistent with these themes (Matikainen, 2017; Scurlock-Evans, Upton \& Upton, 2014; Pighills, Plummer, Harvey, \& Pain, 2013). Universally, the term 'research practice gap' signifies this notional rift between the knowledge generated from research and that which is used in practice. As this void is predicted to lead to substandard patient outcomes and inefficient use of healthcare resources (Leach \& Tucker, 2018; Graham et al., 2006), health professions have a social, fiscal and ethical responsibility to address the gap between research and practice (Leach \& Tucker, 2018).

Traditionally nursing, midwifery and therapy research has been led by academics based in higher education institutions as opposed to in the practice environment in which research generated evidence will be used (Rowley et al., 2012). This two communities model (Wehrens, 2014) can result in an investigator led approach which is considered linear, uni-directional and passive (Nutley, Walter \& Davies, 2014; Bambusch et al., 2008), and so a key contributor to the gap between the generation of research and its uptake. Interaction between these two 


\section{Practitioner engagement by academic researchers}

communities, that is, knowledge producers and knowledge users, is now viewed as critical to research being used in practice (Bowen \& Graham, 2013; Pentland et al., 2011; Oborn, Barrett, \& Racko, 2010) and is an often-cited approach to reduce the gap (Leach \& Tucker, 2018). Combining scientific and clinical expertise can bring varying perspectives and complementary skill sets to a shared common concern (Dluhy et al., 2007), facilitating knowledge production which has greater potential to be contextually relevant and practicable (Pentland et al., 2011).

Recognition of this has resulted in a shift away from the traditional linear model to more socially constructed approaches (Wehrens, 2014; Best \& Holmes, 2010). Engagement and interaction between those who produce and those who use research derived knowledge is a fundamental element of theoretical stances such as Integrated Knowledge Translation (IKT) (Bowen \& Graham, 2013), co-production (Heaton, Day \& Britten, 2016), engaged scholarship (McCormack, 2011) and participatory methodologies (Macaulay, 2017). All have the underlying principle that users of research, such as practitioners, should be involved in the research process to co-create the knowledge that will inform their practice. Most advocate engagement in all stages of the design and conduct of a study. Theory from outside the healthcare remit, shows a potential spectrum of engagement progressing from tokenistic through to democratic partnerships (Martin, 2010; Arnstein, 1969). Greater levels of engagement assume enhanced outcomes with the highest level intended to give ownership of research derived knowledge to increase the chances of application in practice (Martin, 2010).

Within nursing, midwifery and therapy professions engagement between academics and frontline practitioners in the research process is widely advocated (Paget, Caldwell, Murphy, Lilischkis, \& Morrow, 2017; Gelinas, 2016; Pighills et al., 2013; Pentland et al., 2011; Baumbusch et al., 2008) and perceived to impact the design and conduct of a study, clinical practice and individual practitioners' development (Dimova et al., 2018). A strong theoretical case is made that engagement of practitioners in the research process increases relevancy and 


\section{Practitioner engagement by academic researchers}

so can positively impact research implementation potential (Rycroft-Malone et al., 2013; McCormack, 2011). A culture of engaging those who have a stake in healthcare research to have a role beyond that of research participant has been evolving over recent years. This agenda however, has particularly focussed on patient engagement, evidenced through clear organisational mandates (National Institute for Health Research [NIHR], 2018a; Canadian Institute of Health Research [CIHR], 2014), funding body stipulations (UK Research \& Innovation, 2018) and a surge in scholarly work describing and evaluating this activity (PatientCentred Outcomes Research Institute [PCORI], 2018; NIHR, 2018b). Although evidence of practitioner involvement is clear from reviews of stakeholder engagement activity (Camden et al., 2015; Concannon et al., 2014), this is often as a member of a mixed group and therefore it is difficult to discern evidence specific to the practitioner role or its impact. The contribution that the clinical workforce can make to research is starting to attract recognition (Dimova et al., 2018). However, engagement of frontline practitioners as a discrete stakeholder group appears largely unexplored and a review of this practice specific to these disciplines has not yet been conducted. Accordingly, we set out to establish if and how the phenomenon of academic researchers from University settings engaging nurses, midwives and therapists in the research process, in a role other than as a research participant, has been considered in the literature. Specifically, our objectives were to:

- identify evidence of engagement of frontline practitioners from the disciplines of nursing, midwifery, physiotherapy, occupational therapy and speech and language therapy by academic researchers to support the research process in published literature

- establish the type and level of engagement which is reported

- identify reported outcomes, impacts or benefits and establish how these have been established or evaluated 
5. Practitioner engagement by academic researchers

- determine any frameworks, models or theories used to guide reported engagement practices

\section{METHOD}

A scoping review was selected as the most appropriate methodology to address the broad nature of our research question and our desire to explore if and how this phenomenon had been considered in published work. This type of review is defined as a "form of knowledge synthesis that addresses an exploratory research question aimed at mapping key concepts, types of evidence, and gaps in research related to a defined area or field by systematically searching, selecting, and synthesizing existing knowledge" (Colquhoun et al., 2014 p.1292). As opposed to other types of review, a scoping review does not synthesis or review the quality of evidence but systematically maps literature in relation to a specific topic (Peters et al., 2015) to ascertain the extent and nature of the evidence within that field (Tricco et al., 2018). This broad approach enabled us to gain a better understanding of the literature base by mapping what is reported to identify both what is known and any gaps in knowledge (Colquhoun et al., 2014). The scoping review followed the five-stage approach proposed by Arksey and O'Malley (2005, p.22) of (1) identifying the research question; (2) identifying relevant studies; (3) study selection; (4) charting the data; and (5) collating, summarising and reporting the results. Methodological guidance provided by Levac, Colquhoun, \& O'Brien (2010) and the Joanna Briggs Institute (JBI) (Peters et al., 2015) were also used.

\subsection{Stage 1: Identifying the Research Question}

The overarching aim of our review was to identify literature which reports on if and how academic researchers based in University settings engage nursing, midwifery and therapy frontline practitioners from healthcare settings in the design, conduct and/or implementation of their studies where formal organisational collaborative initiatives are not in place. When developing the research question, the JBI scoping review guidance (Peters et al., 2015) 


\section{Practitioner engagement by academic researchers}

recommends clarification of population, concept, and context. In relation to our aim, we clarified the following components, summarised in Table 1:

Population: this review specifically focused on nursing, midwifery and therapy (physiotherapy, occupational therapy, speech and language therapy) frontline practitioners and academic researchers; although the broad term practitioner can refer to a range of job titles, the review concentrated on those whose role is to provide direct clinical care and therefore excluded those in managerial or policy maker roles and practitioners in dedicated research roles. Academic researchers are those employed by a Higher Education Institution or University. We specifically focused on the behaviour of researchers outside of formal system level arrangements based on the belief that many Higher Education Institutions in which academic nursing, midwifery and therapy research is conducted, are not affiliated with formal research practice partnerships.

Concepts: we use the term engagement broadly to refer to involvement in any activity related to at least one stage of the research process (research prioritisation, identifying the topic, protocol design, study conduct, data analysis, dissemination and/or implementation) other than as a study participant which has been initiated by an academic researcher to support the design or conduct of a study.

Context: the context for this review was healthcare settings and the disciplines of nursing, midwifery, occupational therapy, physiotherapy and speech and language therapy.

\section{Stage 2: Identifying relevant studies}

The databases CINAHL, MEDLINE, PsychINFO and Web of Science were searched from 2000 to 2017 using a range of key terms to ensure 'broad coverage' of available literature (Arksey \& O’Malley, 2005). Terms which represent the activity of 'engagement' were situated with keywords which identified the practitioner and the researcher using the adjunct function in all databases to search full texts (Table 2). Identification of search terms was iterative; as 


\section{Practitioner engagement by academic researchers}

initial searches revealed further terms which represented a process of engagement between researchers and practitioners these were added. A citation search of all included papers was also conducted. The search was limited to articles published in English with no restrictions placed on country of publication to obtain a global perspective.

\subsection{Stage 3: Study Selection}

\section{Inclusion and exclusion criteria:}

To be included in the review, papers needed to evaluate or describe an academic researcher's engagement of a nursing, midwifery, physiotherapy, occupational therapy or speech therapy frontline practitioner in an activity related to at least one stage of their study (research prioritisation, identifying the topic, protocol design, study conduct, data analysis, dissemination and/or implementation) other than as a study participant. Where it was not possible to establish if a paper met the inclusion criteria, the corresponding author was contacted for clarity. Peer reviewed papers from 2000 to 2017 were included to map recent and evolutionary changes in reporting and all types of study designs were considered. Conference abstracts, opinion pieces and anecdotal accounts in non-peer reviewed publications did not provide the level of detail required to extract data. A distinct body of literature was found which reports on 'specially created health services research-practice partnerships' (Ovretveit et al., 2014), that is, formal partnership initiatives between academic and healthcare organisations based on a systems model. As this review specifically focuses on the behaviour of researchers outside of such formal organisational arrangements, it was not appropriate to consider this literature within this review. Following removal of duplicates, 982 titles and abstracts were reviewed against the inclusion criteria by the lead researcher (ND). Where assessment could not be made from the title and abstract, full articles were scanned $(n=415)$. A sample of full papers $(n=42)$ were evaluated by two further members of the research team 
8. Practitioner engagement by academic researchers

(PG, KC) to ensure concordance with the study criteria. Three hundred and eighty-three papers were excluded (Figure 1) and 32 retained for analysis.

\subsection{Stage 4: Charting the data}

Papers were transferred to NVivo ${ }^{\mathrm{TM}}$ qualitative data analysis Software Version 12, to collate, organise and analyse content and categorise into those which evaluated and those which described engagement. Data were then extracted to capture the purpose of each paper, disciplines concerned, stage(s) of the research process in which engagement was reported, authorship of papers, terminology used to describe the engagement process, any reported underpinning engagement theory which guided the process and reported outcomes. Where possible, the specific activities in which practitioners were engaged were recorded and delineated into the research phases preparation, execution and translation, in line with previous reviews of patient engagement which have captured similar data (Bethell et al., 2018; Shippee et al., 2015).

\subsection{Stage 5: Collating, summarising and reporting the results}

The fifth and final stage of Arksey and O'Malley's (2005) scoping review framework summarises and reports findings. Results were synthesised using qualitative content analysis techniques to tabulate the data extracted and descriptive statistics used to summarise the characteristics of included articles to align with the review objectives.

\section{FINDINGS}

\subsection{Is there evidence of engagement of frontline practitioners by academic researchers to support the research process?}

Evidence of frontline practitioner engagement by academic researchers in the research process was found in 32 papers, all of which were supplementary to reporting of the findings of the original primary study and which explicitly described $(n=14)$ or reported on evaluation $(n=18)$ of the engagement that had taken place. Most papers originated from the United Kingdom $(n=10)$ and United States $(n=8)$ (Table 4). The majority were published since $2010(n=23)$ with 


\section{Practitioner engagement by academic researchers}

fourteen of these in the latter two years (2015-2017). Papers tended to focus on one discipline; nursing $(n=10)$, occupational therapy $(n=5)$ and midwifery $(n=4)$ with others being multidisciplinary or including groups of mixed stakeholders with at least one practitioner from nursing, midwifery or therapy professions present alongside other health professionals, service users, managers and/or policy makers. Physiotherapists were represented in two papers, one alongside service users and one with occupational therapists. Speech and language therapists were represented in one multidisciplinary paper. The clinical area of focus varied widely across publications (Tables 3a \& 3b). Most related to a single study with three reporting on engagement across multiple studies. Reporting of engagement was most frequently reported in Randomised Controlled Trials $(n=12)$ and implementation activities $(n=8)$ with the remainder providing examples of action research, qualitative and mixed method studies, prioritisation activities and involvement in updating a systematic review.

\subsection{What type of engagement is reported?}

\subsubsection{Stages of the research process}

Papers were analysed to establish the stage(s) of the research process in which academic researchers had engaged with practitioners (Table 5). Six papers appeared to report engagement of practitioners throughout the research process (preparation, execution, translation) (Tables $3 a \& 3 b)$. Four of these studies used an action research design (O'Reillyde Brun et al., 2017; Reed \& Hocking, 2013; Khresheh \& Barclay, 2007; Hummelvoll \& Severinsson, 2005). In a seventh paper, which reported on development of a research protocol, engagement with a Clinical Nurse Specialist (CNS) in the development of the protocol was evident with clear intent to involve the CNS through all subsequent stages of the research process (Fredericks, Martorella, \& Catallo, 2015). In the main, engagement was reported for specific stages of the process and most frequently took place during participant recruitment $(n=9)$, intervention delivery $(n=7)$ or implementation activities $(n=8)$. Engagement in 
implementation related to the development of evidence-based guidelines (O'Reilly- de Brún et al., 2017; Harrison \& Graham, 2012; Renfrew et al., 2008; Dufault \& Sullivan, 2000), a practice report (Kothari, Birch, \& Charles, 2005), a care pathway (Andrew, Johnston, \& Papadopoulou, 2013) and an intervention (Sadler et al., 2017; Eriksson, Erikson, Tham, \& Guidetti, 2017). These activities made use of secondary data in the form of existing published research as opposed to the creation of new empirical primary data. Similarly, physiotherapists were engaged by researchers as part of a mixed stakeholder group to update a systematic review (Pollock et al., 2015).

\subsubsection{Levels of engagement}

Finlayson, Shevil, Mathiowetz, and Matuska (2005) quantified engagement by indicating the range of hours practitioners had dedicated to the study; these varied from 30 to 100 hours. Dyson and Dyson (2014) specifically explored the level of engagement of practitioners who had been asked to collect data alongside their clinical role. Midwives who recruited mothers to a Randomised Controlled Trial (RCT) were identified as repairers, refractors or resisters based on the characteristics of their participation. One quarter were categorised as repairers, that is, they rose to the challenge of the extra workload of research activities and made adjustments to accommodate in order to optimise their contribution. A further quarter were resistors who were unsupportive of the study and collected little data. Half of the midwives refracted through their workload and collected little data resulting in little engagement. Motivation to recruit to an RCT was affected by whether nurses had a say in their involvement or whether they felt put upon when the task was delegated via a colleague (Potter, Dale \& Caramlau, 2009). When exploring perceptions of their role, two studies identified practitioners acting as gatekeepers by making decisions independent of the researcher based on their subjective judgements over participant's eligibility and the study intervention (Stuart, Barnes, Spiby, and Elbourne, 2015; Potter, Dale \& Caramlau, 2009). Poat, McElligott, and Fleming (2003) described their 
observation of the behaviours of midwives within one trial, reporting that it appeared that practitioners' beliefs about the intervention led them to attempt to influence the research outcomes. These examples therefore demonstrate inconsistent behaviours of practitioners within a study and opportunities for bias.

\subsubsection{Authorship}

Three papers explicitly acknowledged that practitioners had engaged in dissemination activities such as manuscript preparation and conference presentations (Campbell, Skidmore, Whyte \& Matthews, 2015; Fredericks et al., 2015; Fitzgerald et al., 2003) but just one having practitioner presence in their authorship (Fitzgerald et al., 2003). Fujimoto, Kon, Takashi, Otaka, and Nakayama (2015) specifically set out to establish collaborative efforts between academics and practice and used practitioner authorship as the measure. Their findings showed limited collaboration in this regard. Capture of named author affiliations of the papers retained for analysis in this review showed that, in the main, authorship was by academic based authors only $(n=19)$. Although practice affiliations of authors were present $(n=13)$, authorship details rarely provided information on the work role of the author or their role within the study. Pollock et al. (2015) listed author contributions identifying that a practice-based author had contributed to the design, coordination and analysis of the study in addition to assisting with drafting the published paper.

\subsection{Is there acknowledgement of the outcomes, impacts or benefits of any reported engagement and how are these evaluated?}

The purpose of each paper was extracted which showed that across evaluative and descriptive papers, authors generally set out to explore the experiences of practitioners or describe the process of engagement that occurred (Tables $3 a \& 3 b$ ). Evaluative papers most frequently aimed to evaluate practitioners' experiences $(n=7)$ or identify challenges and enablers of engagement $(n=4)$. There was limited evidence of papers whose purpose was to specifically 
report on the impact of practitioner engagement on research use, although some examples were found. These related to the engagement of practitioners in the production of implementation products; one specifically posed the question 'does involving clinicians in generating and evaluating a clinical standard lead to changes in practice or improve patient outcomes?' (Dufault \& Sullivan, 2000) whilst Kothari et al. (2005) aimed to determine if interaction between researchers and practitioners promoted the use of research findings. Both adopted a comparative approach to specifically evaluate the impact of practitioner engagement in implementation activities on research use. Kothari et al. (2005) qualitatively compared the reading, processing and application behaviours of practitioners who had interacted with a research team during the development of a report on breast cancer prevention with those of practitioners who had simply received the report. Subjectively, interaction with the research team appeared to influence understanding, value and intention to make use of the report however, there appeared to be no difference between the application of research findings between the two practitioner groups. Dufault and Sullivan (2000) found that patients who received care from a practitioner who followed a research-based pain management standard which they had been directly involved in producing experienced improved health outcomes when compared to a control group who had not received treatment via the collaboratively produced standards. Conclusions were drawn from data obtained objectively by comparing patient outcomes of pain, quality of life and satisfaction measures. Papers whose purpose related specifically to the impact on practice when practitioners were engaged in preparatory or execution phases of the research process were sparse. Occupational therapists were asked to reflect on the influence engagement in stages of a Randomised Controlled Trial had on their practice (Finlayson et al., 2005) whilst Ishimaru, Yamada, Matsushita, and Umezu (2016) evaluated effects of participation in multiple collaborative projects by asking nurses to report their perceptions of practice improvements. 
To obtain further data, the main types of outcomes reported within evaluative papers and the methods used to identify these outcomes were extracted (Table 3a). Thirteen of the eighteen adopted a qualitative approach to explore engagement experiences using focus groups, interviews and reflective accounts. Likert scale surveys were used in three studies to evaluate experiences with two exploring practitioners' experiences further through open comments (Pollock et al., 2015) and interviews (Ishimaru et al., 2016). Specific strategies to facilitate engagement were also evaluated in two papers; an online approach to prioritising patientcentred research topics (Khodyakov et al., 2017) and the use of Participatory Learning and Action (PLA) techniques for data generation and co-analysis (O'Reilly-de Brun et al., 2017). Fujimoto et al. (2015) explored levels of engagement by attempting to identify collaboration levels through citation data whilst Dyson and Dyson, (2014) classified practitioners' roles to determine their level of engagement.

Establishing and theming outcomes in descriptive papers proved challenging as these tended to be narrative in nature, reporting researchers' general reflections, perspectives or thoughts on the process, however it was clear that the focus of these papers was on the benefits, challenges and lessons learnt from engagement experiences, most often taken from the author's perspective. As authors predominately had academic affiliations, these descriptions appear to have the voice of the researcher (Table 3b). Although one paper provided an example of active practitioner input to protocol design which illustrated that changes were made (Fredericks et al., 2015), no papers formally evaluated specific changes made to the design or conduct of a study following engagement of practitioners in the research process. Some authors acknowledged the role clinical input had on overcoming research challenges and a potentially positive influence on the validity of the study. Examples included seeking clinical views on validity and usefulness of proposed data collection procedures (Bullen, Maher, Rosenberg, \& Smith, 2014; Pollock et al., 2015) and input that could optimise study participation in the 
clinical context (Gettrust, Hagle, Boaz, \& Bull, 2016; Campbell et al., 2015; Roll et al., 2013). In addition, no formal evaluation of the impact of engagement on practitioners' research skills was noted.

\subsection{What frameworks, models or theories are used to guide reported engagement?}

Content analysis showed that eleven papers reported use of theoretical engagement principles (Table 6) with a variety of theories employed to guide practice and more than one theory referred to in some instances (Harrison \& Graham, 2012; Hummelvoll \& Severinsson, 2005). Theories used included Integrated Knowledge Translation (IKT), co-production principles and participatory methodologies. The term 'collaborative research' was used in different ways; within a particular collaborative model (Dufault \& Sullivan, 2000), to refer to a collaborative research team (Fitzgerald et al., 2003) in relation to an action research approach (Reed \& Hocking, 2013) and with no definition (Stockwell-Smith, Moyle, Kellett, \& Brodaty, 2015). Some authors explicitly presented models which had guided practices such as the Collaborative Research Utilisation (CRU) approach (Dufault \& Sullivan, 2000), Framework of Interaction and Research Utilisation (Kothari et al., 2005) and Practice-Research Engagement (PRE) (Khresheh \& Barclay, 2007). In general, however, researchers who engaged practitioners did not appear to adopt a theoretical engagement approach other than emphasising the role practitioners played in the research process.

A frequency count of full texts identified that in descriptive papers, the most common term used was a derivative of 'engagement' whilst in evaluative papers derivatives of 'involvement' were more widely adopted (Figure 2). Thirty of the analysed papers (94\%) used the four terms participate, involve, collaborate and engagement (or derivatives of) interchangeably throughout the text. Inclusive words such as co-produce, co-create and 'members of the research team' were used as were reductionist terms such as hired hand and recruiter. Operational definitions of these terms were not provided. 


\section{DISCUSSION}

This scoping review includes 32 papers which report on university based academic researchers engagement of frontline practitioners, from nursing, midwifery and therapy professions in the research process, in a role other than as a study participant. The review has achieved its aim by sourcing and reporting on the literature base relating to this topic, demonstrating a heterogeneous evidence base for this activity across these healthcare disciplines. The included papers evidence that academic researchers are engaging with practitioners in their research endeavours and that efforts are made to evaluate and reflect on this process. There is a clear split between evaluative reporting and description of experiences with considerable variation across all papers in the type of engagement, what is evaluated and the focus of reporting making identification of distinguishing patterns or trends challenging. Considering the global nature of the search, the number of articles which met the review criteria was low; this yield is not necessarily reflective of engagement practices but instead indicates that reporting of this activity in peer reviewed publications is limited. Reporting does, however, appear to be on the increase with a clear rise in publications during the latter two years perhaps suggesting an emerging topic and possible increase in engagement practices.

As first thought, differences can be noted when publication activity is compared to that of other healthcare research stakeholder groups; the literature base relating to engagement with patients and the public in health research contains a substantially higher number of papers, evidenced in systematic reviews (Shippee et al., 2015; Brett et al., 2014; Domecq et al., 2014). This is perhaps reflective of policy initiatives and research funding body mandates to engage with this stakeholder subgroup whereas the drive to ensure an engagement culture specific to practitioners as a discrete stakeholder group appears less apparent. Although the diversity across the literature base, coupled with a relatively low yield, makes analysis and synthesis of 
papers challenging, the data extracted from reviewed papers enables gaps to be identified and considerations for practice and future research to be explored.

\subsection{Engagement in the stages of the research process}

Engagement was most frequently reported to occur in just one element of the research process with practitioners often engaged to carry out a specific role in the execution phase of a study, such as delivery of the study intervention or recruitment of participants. This contradicts the strong assertion of theories such as IKT that practitioners should be involved across the research process. Collaboration during research formulation and study design to identify the knowledge needs of health professionals is deemed an important requirement to produce clinically relevant, useful and practicable new knowledge (Bowen \& Graham, 2013; Andrew et al., 2013; Krebbekx, Harting, \& Stronks, 2012; Green, 2008) and ensure commitment to the study (Brown, Bammer, Batliwala, \& Kunreuther, 2003). However, little evidence of engagement in the preparatory phase in the form of conceptualisation or protocol design was present in the literature scoped. Engaging practitioners in subsequent execution activities when they have not contributed to the protocol design limits their opportunity to voice their research needs or apply their experiential knowledge to study planning. Subsequently, lack of study ownership could create reluctance to engage in subsequent stages of the research process. That levels and type of engagement can impinge on the outcome and success of practitioner engagement is addressed in a small number of papers within this review and has been noted in wider healthcare research (Rooshenas et al., 2016; Ziebland et al, 2007). The 'hired hand' effect and subsequent resistance to a study can result in practitioners' attitudes influencing important elements such as participant recruitment (Dyson \& Dyson, 2014). Examples illustrate how practitioner buy-in can be affected by concerns around elements of a study, such as eligibility criteria and the study intervention, influencing behaviours in their role within the research and potentially impacting internal and/or external validity (Dyson \& Dyson, 2014; 
Stuart et al., 2015; Poat et al., 2003). Such reductionist roles limit scope to draw on practitioners' experiential knowledge, restricting the meaningful contribution made and the ability for this type of engagement to increase the likelihood of the knowledge produced being used in practice. This reinforces the call for further research to identify which forms of engagement are productive and what their impact can be (Bowen \& Graham, 2013).

In the translational phase of the research process, it is encouraging to see practice affiliations within authorship listings and engagement of practice-based personnel in dissemination activity. However, affiliations can reveal little about the work role of practice-based authors or the full nature of the engagement beyond manuscript preparation. This is compounded by many papers reporting engagement activities yet no reference to practice-based authors reinforcing the academic nature of publication and dissemination activities. Engagement during implementation activities was prevalent in this review; researchers recognise the value of working with practitioners at the point of care (Harrison \& Graham, 2012) and the positive impact this may have in the translation of research into practice. Encouraging effects were noted for patient outcomes and the use of research findings when practitioners were engaged in the production of implementation products. However, the case for practitioner engagement asserts their role in the preparation and execution phases of the production of research derived knowledge to realise the benefits for research use as opposed to directing engagement to only the translation phase.

\subsection{Evaluation of engagement}

Papers focussed on a range of outcomes, most often the benefits and challenges of the engagement process. Lessons which can be learnt from these experiences and the benefits realised by practitioners for their professional and practice development are arguably valuable. However, despite claims that practitioner engagement is imperative to produce research which is more readily transferable into practice, evaluations which measure these specific impacts on 
evidence-based practice are sparse. Empirical evidence to support the notion that engagement of practitioners by academic researchers bridges the gap between research and practice is lacking which prohibits demonstration of the value that can be added. Qualitative methods dominate the evaluative literature base, with most researchers exploring the practitioner experience, potentially biased by the collection of this data by the researchers themselves. Coupled with a tendency for researchers to offer reflective narrative on their experiences through descriptive publications, the result is a subjective evidence base built on a variable range of personal perspectives. The challenges of measuring impact of engagement on practice outcomes empirically are of course recognised and have been experienced with other stakeholder groups (Esmail, Moore, \& Rein, 2015; Edelman \& Barron, 2016). When considered in tandem with the issue of the optimal level of engagement and stages of the research process in which practitioners should be engaged, what is clearly missing from this literature base is the evidence which links specific engagement activities with specific intended outcomes. Hence the true impact of the varying types and levels of engagement on evidencebased practice is unclear.

\subsection{Terminology and theoretical approaches}

There has been a surge of interest in recent years in approaches which stress the value of engaging practitioners across the research process. Certainly, papers considered in this review spoke of the desire to co-create, co-design and co-produce research with the practitioners in question. However, many did not evidence use of a theoretical approach and in addition tended towards engagement in just one aspect of the research process as opposed to spanning a study as these co-productive approaches postulate. The case is now made for engagement principles to be explicit in all research designs (McCormack, 2011; Pentland et al., 2011). Researchers therefore must look to existing engagement paradigms to ensure meaningful engagement which will result in research use (Bowen \& Graham, 2013). However, it appears more work may be 
required to guide researchers in this regard. It is inevitable that engagement levels will vary in healthcare research dependent on the nature of the study and that barriers may limit the feasibility of a full participatory approach (Bowen \& Graham, 2013). A better understanding of how meaningful engagement can be achieved when the intended goal is production of relevant and practicable knowledge to affect evidence-based practice is therefore required so strategies can be employed, and action taken to embed such practices in to the research design. Developing this understanding may need to begin by establishing consistency around the language used to describe this activity. The review confirmed that 'engagement' is used regularly but with near equal frequency and interchangeably with other synonyms such as 'involvement', 'participation' and 'collaboration', which are open to interpretation. As most authors do not offer an operational definition of what constitutes engagement, or their chosen term, there is both ambiguity and inconsistency as to what the terminology used signifies. Coupled with the theoretical labels and the use of terms such as exchange (Bambusch et al., 2008) and interaction (Nutley, Walter \& Davis, 2014; Bowen \& Graham, 2013) to represent this activity, such variation is potentiality a limiting factor in building an evidence base to establish the essence of what practitioner engagement truly means or what is required to achieve its intended goals. This concept aligns closely with the culture of public engagement in research (Bowen \& Graham, 2013); in the United Kingdom, consistent use of the term 'Patient and Public Involvement' (PPI) has led to a common language, clear definitions and operational guidance which have moved the agenda forward and enabled evidence to be generated in relation to this stakeholder subgroup. Established definitions within 'Patient and Public Involvement' show fundamental differences in terms, for example, 'involvement' represents a more active role in the research process than 'engagement' (NIHR, 2018d). A similar consistency of terminology and corresponding taxonomy now needs to evolve around practitioner engagement (Dimova et al., 2018). 


\section{CHALLENGES AND LIMITATIONS OF THE REVIEW}

Challenges were encountered by the author in the process of sourcing publications to include in this review. A range of synonyms exist for the process of engagement, recognised as a challenge by authors who have previously analysed literature in the stakeholder engagement field (Camden et al., 2015; Concannon et al., 2014). Although a comprehensive search strategy and iterative approach optimised the yield, overlooking publications is a possibility and a frequently reported limitation of scoping reviews (Pham et al., 2014). Best efforts were made to ensure papers met the review criteria and authors contacted when there was doubt; it was often difficult to apply inclusion and exclusion criteria to establish if engagement was academically initiated, based in a formal organisational partnership arrangement or to discern internal or external research teams as such data was not always reported by authors (French \& Stavropoulou, 2016). It is acknowledged that research with academics is often initiated from practice, and so further work to consider the extent of publications in this regard may also be informative. A scoping review is not intended to be exhaustive (Levac et al., 2010); rather to enable a breadth of publication types to be represented. Indeed, as the review has shown, much of the literature dedicated to this topic is narrative and reflective in nature and therefore may lend itself well to discussions within grey literature, conference presentations and social media. However, such resources were not captured in this review potentially overlooking further examples and experiences of engagement practices. Although the disciplines of nursing, midwifery and occupational therapy have been given fair representation by the papers found, physiotherapy and speech therapy appear underrepresented in the literature reviewed. Evaluation of the quality of the literature was not within the remit of a scoping review (Levac et al., 2010), therefore, further appraisal of the methods used to evaluate engagement and synthesis of findings is required.

\section{CONCLUSION AND RECOMMENDATIONS FOR RESEARCH AND PRACTICE}


The aim of this scoping review was to map literature in the nursing, midwifery and therapy fields (physiotherapy, occupational therapy and speech and language therapy) which reports on engagement of frontline practitioners in the research process by University based academic researchers. Whilst the low yield and heterogeneity of identified papers has made identification of patterns or themes challenging, gaps in the literature can be established and consideration given to future practice and research needs. This review has shown: a) limited reporting of nursing, midwifery and therapy practitioner engagement in the research process b) engagement is largely focused on one aspect of the research process in any given study c) limited objective evaluation of the influence of engagement levels and types on the research-practice gap d) limited use of theory to guide engagement practices to achieve outcomes which will positively impact the research-practice gap and e) use of inconsistent and undefined terms to describe this activity.

Engagement of practitioners in the research process by academic researchers is occurring in healthcare research, albeit, from what the literature suggests, inconsistently and with little empirical evidence of its added value. Although advocated, the need for practitioner engagement to be embedded into the research process to enhance relevance and utility, still appears open for debate and what constitutes productive and meaningful engagement which can affect the use of research derived evidence in practice is unclear. This largely stems from the lack of empirical evidence to support the belief that such practices can positively influence the research practice gap. Evaluations should therefore develop a greater focus on establishing what is meant by meaningful engagement and measuring intended impacts, that is, the influence of engagement on research utilisation and ultimately health outcomes. Factors contributing to the limited and inconsistent literature base must be addressed if knowledge in relation to this activity is to be advanced and the culture of engagement of practitioners in research is to be further developed. The challenges of developing an evidence base to support 
effectiveness of engagement activities is clear from the experiences of the Public and Patient Involvement (PPI) agenda which, despite a growing body of literature and infrastructures, continues to require further development and evaluation. However, what the PPI agenda does possess is a common language to move the agenda forward and enable evidence to be generated and which is supported by many research funders who make it a requirement for PPI to be evidenced in applications. This review very specifically focused on contexts where dedicated collaborative, cross organisational programmes are not in place. However, it is recognised that globally there are several national initiatives funded specifically to create academic-practice partnerships and so facilitate engagement between academic and practice communities. A further body of literature which both describes and evaluates this parallel context is evolving from these initiatives and so future work should explore if lessons can be learnt from these experiences to inform practices for those not situated in such partnership arrangements. Fundamentally, further insight is required into what type of engagement works and how to enable researchers to ensure engagement is embedded into academic research to positively influence use of the knowledge produced in clinical practice. 


\section{REFERENCES}

Albers, L.L., \& Sedler, K.D. (2004). Clinician perspectives on participation in research. Journal of Midwifery and Women's Health, 49(1), 47-50.

Andrew, J., Johnston, B., \& Papadopoulou, C. (2013). Community nurses' participation in palliative care research: The Dignity Care Pathway. British Journal of Community Nursing, 18(7).

Arksey, H., \& O'Malley, L. (2005). Scoping studies: towards a methodological framework. International journal of social research methodology, 8(1), 19-32.

Arnstein, S. (1969) A ladder of citizen participation, Journal of the American Institute of Planners, 35:4, 216-224, DOI: 10.1080/01944366908977225paget

Baumbusch, J.L., Kirkham, S.R., Khan, K.B., McDonald, H., Semeniuk, P., Tan, E., \&Anderson, J.M. (2008). Pursuing common agendas: A collaborative model for knowledge translation between research and practice in clinical settings. Research in Nursing and Health, 31(2), 130-140.

Best, A., \& Holmes, B. (2010). Systems thinking, knowledge and action: towards better models and methods. Evidence \& Policy: A Journal of Research, Debate and Practice, 6(2), 145-159.

Bethell, J., Commisso, E., Rostad, H.M., Puts, M., Babineau, J., Grinbergs-Saull, A., Wighton, M.B., Hammel, J., Doyle, E., Nadeau, S. and McGilton, K.S. (2018). Patient engagement in research related to dementia: A scoping review. Dementia, 17(8), pp.944-975.

Boase, S., Kim, Y., Craven, A., \& Cohn, S. (2012). Involving practice nurses in primary care research: the experience of multiple and competing demands. Journal of Advanced Nursing, 68(3), 590-599. DOI: 10.1111/j.1365-2648.2011.05764.x 
Bowen, S.J., \& Graham, I.D. (2013). From knowledge translation to engaged scholarship: Promoting research relevance and utilization. Archives of Physical Medicine and Rehabilitation, 94(1 SUPPL).

Brett, J., Staniszewska, S., Mockford, C., Herron- Marx, S., Hughes, J., Tysall, C., \& Suleman, R. (2014). Mapping the impact of patient and public involvement on health and social care research: a systematic review. Health Expectations, 17(5), 637-650.

Brown, L.D., Bammer, G., Batliwala, S., \& Kunreuther, F. (2003). Framing practice-research engagement for democratizing knowledge. Action Research, 1(1), 81-102.

Bullen, T., Maher, K., Rosenberg, J.P., \& Smith, B. (2014). Establishing research in a palliative care clinical setting: perceived barriers and implemented strategies. Applied Nursing Research, 27(1), 78-83.

Burford, S., Park, S., DawDa, P., \& Burns, J., (2015). Participatory research design in mobile health: Tablet devices for diabetes self-management. Communication \& Medicine, 12(2/3), 145.

Camden, C., Shikako-Thomas, K., Nguyen, T., Graham, E., Thomas, A., Sprung, J., Morris, C., \& Russell, D.J. (2015). Engaging stakeholders in rehabilitation research: a scoping review of strategies used in partnerships and evaluation of impacts. Disability and Rehabilitation, 37(15), 1390-1400.

Campbell, G.B., Skidmore, E.R., Whyte, E.M., \& Matthews, J.T. (2015). Overcoming practical challenges to conducting clinical research in the inpatient stroke rehabilitation setting. Topics in Stroke Rehabilitation, 22(5), 386-394.

Canadian Institute of Health (2014). Strategy for Patient-Oriented Research Patient Engagement Framework Retrieved from http://www.cihrirsc.gc.ca/e/documents/spor_framework-en.pdf 
Colquhoun, H.L., Levac, D., O'Brien, K.K., Straus, S., Tricco, A.C., Perrier, L., Kastner, M., \& Moher, D. (2014). Scoping reviews: time for clarity in definition, methods, and reporting. Journal of clinical epidemiology, 67(12), 1291-1294.

Concannon, T.W., Fuster, M., Saunders, T., Patel, K., Wong, J.B., Leslie, L.K., \& Lau, J. (2014). A systematic review of stakeholder engagement in comparative effectiveness and patient-centered outcomes research. Journal of General Internal Medicine, 29(12), 1692.

Di Bona, L., Wenborn, J., Field, B., Hynes, S.M., Ledgerd, R., Mountain, G., \& Swinson, T. (2017). Enablers and challenges to occupational therapists' research engagement: A qualitative study. British Journal of Occupational Therapy, 80(11), 642-650.

Dimova, S., Prideaux, Ball, S., Harshfield, A., Carpenter, A., and Marjanovic, S. (2018) Enabling NHS staff to contribute to research: Reflecting on current practice and informing future opportunities, Santa Monica, Calif.: RAND Corporation, Retrieved from https://www.rand.org/pubs/research_reports/RR2679.html

Dluhy, N., Christopher, K., Gramling, K., Leffers, J., Russell, G.E. and Sethares, K. (2007). Embedded, engaged, evolving: A consortium of nurse researchers and clinicians. Nursing Outlook, 55(2), 79-84.

Domecq, J.P., Prutsky, G., Elraiyah, T., Wang, Z., Nabhan, M., Shippee, N., Brito, J.P., Boehmer, K., Hasan, R., Firwana, B., \& Erwin, P. (2014). Patient engagement in research: a systematic review. BMC Health Services Research, 14(1), 89.

Dufault, M.A., \& Sullivan, M. (2000). A collaborative research utilization approach to evaluate the effects of pain management standards on patient outcomes. Journal of Professional Nursing, 16(4), 240-250. 
Dyson, S., \& Dyson, S. (2014). The politics of health services research: health professionals as hired hands in a commissioned research project in England. Sociological Research Online, 19(3), 1-11 DOI: 10.5153/sro.3457

Edelman, N., \& Barron, D. (2016). Evaluation of public involvement in research: time for a major re-think? Journal of Health Services Research \& Policy, 21(3), 209-211.

Eriksson, C., Erikson, A., Tham, K., \& Guidetti, S. (2017). Occupational therapist's experiences of implementing a new complex intervention in collaboration with researchers: a qualitative longitudinal study. Scandinavian Journal of Occupational Therapy, 24(2), 116-125.

Eriksson, C., Tham, K., \& Guidetti, S. (2013). Occupational therapists' experiences in integrating a new intervention in collaboration with a researcher. Scandinavian Journal of Occupational Therapy, 20(4), 253-263.

Esmail, L., Moore, E., \& Rein, A. (2015). Evaluating patient and stakeholder engagement in research: moving from theory to practice. Journal of Comparative Effectiveness Research, 4(2), 133-145.

Finlayson, M., Shevil, E., Mathiowetz, V., \& Matuska, K. (2005). Reflections of occupational therapists working as members of a research team. Australian Occupational Therapy Journal, 52(2), 101-108.

Fitzgerald, M., Milberger, P., Tomlinson, P.S., Peden-Mcalpine, C., Meiers, S.J., \& Sherman, S., (2003). Clinical nurse specialist participation on a collaborative research project: barriers and benefits. Clinical Nurse Specialist, 17(1), 44-49.

Fredericks, S., Martorella, G., \& Catallo, C. (2015). Using knowledge translation as a framework for the design of a research protocol. International Journal of Nursing Practice, 21(S2), 157-163.

French, C. and Stavropoulou, C. (2016). Specialist nurses' perceptions of inviting patients to 
participate in clinical research studies: a qualitative descriptive study of barriers and facilitators. BMC Medical Research Methodology, 16(1), 96.

Fujimoto, S., Kon, N., Takashi, N., Otaka, Y., \& Nakayama, T. (2015). Patterns in the collaboration of practitioners and researchers in the use of electrical stimulation to treat stroke patients: a literature review. Journal of Physical Therapy Science, 27(9), 30033005.

Funk, S.G., Champagne, M.T., Wiese, R.A. and Tornquist, E.M. (1991). BARRIERS: the barriers to research utilization scale. Applied Nursing Research, 4(1), 39-45.

Gélinas, I. (2016). Partnership in research: A vehicle for reaching higher summits. Canadian Journal of Occupational Therapy, 83(4), 204-215.

Gettrust, L., Hagle, M., Boaz, L., \& Bull, M. (2016). Engaging nursing staff in research: the clinical nurse specialist role in an academic-clinical partnership. Clinical Nurse Specialist, 30(4), 203-207.

Graham, I.D., Logan, J., Harrison, M.B., Straus, S.E., Tetroe, J., Caswell, W. and Robinson, N. (2006). Lost in knowledge translation: time for a map?. Journal of Continuing Education in the Health Professions, 26(1), 13-24.

Green, LW. (2008). Making research relevant: if it is an evidence-based practice, where's the practice-based evidence? Family Practice, 25: i20-i24.

Harrison, M.B., \& Graham, I.D. (2012). Roadmap for a participatory research-practice partnership to implement evidence. Worldviews on Evidence-Based Nursing, 9(4), 210-220.

Heaton, J., Day, J. and Britten, N. (2016). Collaborative research and the co-production of knowledge for practice: an illustrative case study. Implementation Science, 11(1), 20.

Hummelvoll, J.K., \& Severinsson, E. (2005). Researchers' experience of co- operative inquiry in acute mental health care. Journal of Advanced Nursing, 52(2), 180-188. 
Ishimaru, M., Yamada, Y., Matsushita, M., \& Umezu, M. (2016). The effects of collaborative research- based programming on public health nurses and their practice. International Journal of Nursing Practice, 22(S1), 48-55.

Khodyakov, D., Grant, S., Meeker, D., Booth, M., Pacheco-Santivanez, N., \& Kim, K.K. (2017). Comparative analysis of stakeholder experiences with an online approach to prioritizing patient-centered research topics. Journal of the American Medical Informatics Association, 24(3), 537-543.

Khresheh, R., \& Barclay, L. (2007). Practice-research engagement (PRE) Jordanian experience in three Ministry of Health hospitals. Action Research, 5(2), 123-138.

Kothari, A., Birch, S., \& Charles, C. (2005). "Interaction" and research utilisation in health policies and programs: does it work? Health Policy, 71(1), 117-125.

Krebbekx, W., Harting, J., \& Stronks, K. (2012). Does collaborative research enhance the integration of research, policy and practice? The case of the Dutch Health Broker Partnership. Journal of health Services Research \& Policy, 17(4), 219-229.

Leach, M.J. and Tucker, B. (2018). Current understandings of the research-practice gap in nursing: A mixed-methods study. Collegian, 25(2), 171-179.

Levac, D., Colquhoun, H., \& O'Brien KK. (2010). Scoping studies: advancing the methodology. Implementation Science, 5(1), 69. DOI: 10.1186/1748-5908-5-69

Macaulay, A.C. (2017). Participatory research: What is the history? Has the purpose changed?. Family Practice, 34(3), 256-258

McCormack, B. (2011). Engaged scholarship and research impact: Integrating the doing and using of research in practice. Journal of Research in Nursing, 16(2), 111-127.

Martin, S. (2010). Co-production of social research: strategies for engaged scholarship, Public Money \& Management, 30(4), 211-218. DOI: 10.1080/09540962.2010.492180 
Matikainen, M. (2017). Promoting the legitimacy and agency of new graduate nurses' participation in nursing research. Contemporary Nurse, 53(3), 293-301, DOI: $10.1080 / 10376178.2017 .1338524$

Mulhall, A. (2002). Nursing research and nursing practice: an exploration of two different cultures. Intensive and Critical Care Nursing, 18(1), 48-55.

National Institute for Health Research (2018a). INVOLVE Evidence library. Retrieved from http://www.invo.org.uk/resource-centre/libraries/evidence-library/

National Institute for Health Research (2018b). National Standards for Public Involvement in Research. Retrieved from https://www.nihr.ac.uk/news-andevents/documents/Public_Involvement_Standards_March\%202018_WEB.pdf

National Institute for Health Research (2018c). Briefing notes for researchers: public involvement in NHS, public health and social care research. Retrieved from http://www.invo.org.uk/wpcontent/uploads/2014/11/9938_INVOLVE_Briefing_Notes_WEB.pdf

Nutley, S., Walter, I., \& Davies H. (2014). Using Evidence: How Research Can Inform Public Services. The University of Chicago Press Books Chicago

Oborn, E., Barrett, M., \& Racko, G. (2010). Knowledge translation in healthcare: A review of the literature. Cambridge Judge Business School, University of Cambridge.

O'Reilly- de Brún, M., Brún, T., O'Donnell, C.A., Papadakaki, M., Saridaki, A., Lionis, C., Burns, N., Dowrick, C., Gravenhorst, K., Spiegel, W., \& Van Weel, C. (2017). Material practices for meaningful engagement: an analysis of participatory learning and action research techniques for data generation and analysis in a health research partnership. Health Expectations, 1-12 DOI: 10.1111/hex.12598

Ovretveit, J., Hempel, S., L. Magnabosco, J., S. Mittman, B., V. Rubenstein, L., \& A. Ganz, D. (2014). Guidance for research-practice partnerships (R-PPs) and collaborative 
research. Journal of Health Organization and Management, 28(1), 115-126.

Paget, S.P., Caldwell, P.H., Murphy, J., Lilischkis, K.J., \& Morrow, A.M. (2017). Moving beyond 'not enough time': factors influencing paediatric clinicians' participation in research. Internal Medicine Journal, 47(3), 299-306.

Patient-Centred Outcomes Research Institute (2018). Engagement in Health Research Literature Explorer. Retrieved from https://www.pcori.org/literature/engagementliterature

Pentland, D., Forsyth, K., Maciver, D., Walsh, M., Murray, R., Irvine, L., \& Sikora, S. (2011). Key characteristics of knowledge transfer and exchange in healthcare: integrative literature review. Journal of Advanced Nursing, 67(7), 1408-1425.

Peters, M.D., Godfrey, C.M., Khalil, H., McInerney, P., Parker, D. and Soares, C.B. (2015). Guidance for conducting systematic scoping reviews. International Journal of Evidence-based Healthcare, 13(3), 141-146.

Pham, M.T., Rajić, A., Greig J.D., Sargeant, J.M., Papadopoulos, A., \& McEwen, S.A. (2014). A scoping review of scoping reviews: advancing the approach and enhancing the consistency. Research Synthesis Methods, 5(4), 371-385. doi:10.1002/jrsm.1123.

Pighills, A.C., Plummer, D., Harvey, D., \& Pain, T. (2013). Positioning occupational therapy as a discipline on the research continuum: Results of a cross- sectional survey of research experience. Australian Occupational Therapy Journal, 60(4), 241-251.

Poat, A., McElligott, M., \& Fleming, V. (2003). How midwives' attitudes can affect the research process. British Journal of Midwifery, 11(6), 396-400.

Pollock, A., Campbell, P., Baer, G., Choo, P.L., Morris, J., \& Forster, A. (2015). User involvement in a Cochrane systematic review: using structured methods to enhance the clinical relevance, usefulness and usability of a systematic review update. Systematic Reviews, 4(1), 55. 
Potter, R., Dale, J. and Caramlau, I. (2009). A qualitative study exploring practice nurses' experience of participating in a primary care-based randomised controlled trial. Journal of Research in Nursing, 14(5), pp.439-447.

Reed, K., \& Hocking, C. (2013). Re- visioning practice through action research. Australian Occupational Therapy Journal, 60(3), pp.181-188 DOI: 10.1111/1440-1630.12033

Renfrew, M.J., Dyson, L., Herbert, G., McFadden, A., McCormick, F., Thomas, J., \& Spiby, H. (2008) Developing evidence- based recommendations in public healthincorporating the views of practitioners, service users and user representatives. Health Expectations, 11(1), 3-15.

Roll, L., Stegenga, K., Hendricks-Ferguson, V., Barnes, Y.J., Cherven, B., Docherty, S.L., Robb, S.L., \& Haase, J.E. (2013) Engaging nurses in research for a randomized clinical trial of a behavioral health intervention. Nursing Research and Practice, 2013.

Rooshenas, L., Elliott, D., Wade, J., Jepson, M., Paramasivan, S., Strong, S., Wilson, C., Beard, D., Blazeby, J.M., Birtle, A., \& Halliday, A. (2016) Conveying equipoise during recruitment for clinical trials: qualitative synthesis of clinicians' practices across six randomised controlled trials. PLoS Medicine, 13(10), p.e1002147.

Rowley, E., Morriss, R., Currie, G., \& Schneider, J. (2012). Research into practice: collaboration for leadership in applied health research and care (CLAHRC) for Nottinghamshire, Derbyshire, Lincolnshire (NDL). Implementation Science, 7(1), 40. Rycroft-Malone, J., Wilkinson, J., Burton, C.R., Harvey, G., McCormack, B., Graham, I., \& Staniszewska, S. (2013). Collaborative action around implementation in Collaborations for Leadership in Applied Health Research and Care: towards a programme theory. Journal of Health Services Research \& Policy, 18(3_suppl), 13-26.

Sadler, E., Porat, T., Marshall, I., Hoang, U., Curcin, V., Wolfe, C.D., \& McKevitt, C. (2017). Shaping innovations in long-term care for stroke survivors with multimorbidity through 
stakeholder engagement. PloS One, 12(5), p.e0177102.

Scurlock-Evans, L., Upton, P. and Upton, D. (2014). Evidence-based practice in physiotherapy: a systematic review of barriers, enablers and interventions. Physiotherapy, 100(3), 208-219.

Shippee, N.D., Domecq Garces, J.P., Prutsky Lopez, G.J., Wang, Z., Elraiyah, T.A., Nabhan, M., Brito, J.P., Boehmer, K., Hasan, R., Firwana, B. and Erwin, P.J. (2015). Patient and service user engagement in research: a systematic review and synthesized framework. Health Expectations, 18(5), 1151-1166.

Stockwell-Smith, G., Moyle, W., Kellett, U., \& Brodaty, H., (2015). Community practitioner involvement in collaborative research. Dementia, 14(4), 450-467.

Stuart, J., Barnes, J., Spiby, H., \& Elbourne, D. (2015). Understanding barriers to involving community midwives in identifying research participants; experience of the first steps randomised controlled trial. Midwifery, 31(8), 779-786.

Tricco, A.C., Lillie, E., Zarin, W., O'Brien, K.K., Colquhoun, H., Levac, D., Moher, D., Peters, M.D., Horsley, T., Weeks, L. and Hempel, S. (2018). PRISMA extension for scoping reviews (PRISMA-ScR): checklist and explanation. Annals of Internal Medicine, 169(7), 467-473.

UK Research and Innovation (2018). Research council partners and public engagement with research. Retrieved from https://www.ukri.org/public-engagement/research-councilpartners-and-public-engagement-with-research/

Wehrens, R. (2014). Beyond two communities-from research utilization and knowledge translation to co-production? Public Health, 128(6), pp.545-551.

Ziebland, S., Featherstone, K., Snowdon, C., Barker, K., Frost, H., \& Fairbank, J. (2007). Does it matter if clinicians recruiting for a trial don't understand what the trial is really about? 
33. Practitioner engagement by academic researchers

Qualitative study of surgeons' experiences of participation in a pragmatic multi-centre RCT. Trials, 8 (1) 4. 
34. Practitioner engagement by academic researchers

Table 1: Definitions of key concepts within the research question

\begin{tabular}{ll}
\hline Concept & Definition \\
\hline Frontline practitioner & A member of the named professions whose role encompasses delivery \\
& of care directly to a patient(s); \\
\hline Academic researcher & Those employed to carry out research by a Higher Education Institute \\
& (HEI); \\
\hline Engagement in research & Active involvement in at least one stage of the research process \\
process & (research prioritisation, identifying the topic, protocol design, study \\
& conduct, data analysis, dissemination and/or implementation) other \\
& than as a study participant and which was initiated by the academic \\
& researcher. \\
& A paper in which a defined method is used to evaluate, measure or \\
& assess the phenomena under consideration \\
\hline Evaluative papers & A paper which provides description of the phenomena under \\
& consideration
\end{tabular}


35. Practitioner engagement by academic researchers

Table 2: Search terms used to identify relevant studies for inclusion in the scoping review

\begin{tabular}{l}
\hline Search Terms \\
(interact* OR engage* OR involve* OR participat* OR collaborat* OR partner* OR co- \\
produc* OR co-operat* OR co-creat* OR 'integrated knowledge translation') AND \\
(nurs* OR midwi* OR therap* OR practitioner* OR clinician*) AND \\
Researcher*
\end{tabular}

Table 3a and 3b: See additional file 
Table 4: Key Characteristics of papers included in the scoping review

\begin{tabular}{|c|c|c|c|}
\hline & $\begin{array}{c}\text { Evaluative } \\
(\mathrm{n}=18)\end{array}$ & $\begin{array}{c}\text { Descriptive } \\
(\mathrm{n}=14)\end{array}$ & $\begin{array}{c}\text { Total } \\
(n=32)\end{array}$ \\
\hline \multicolumn{4}{|l|}{ Discipline } \\
\hline Nursing & 6 & 4 & 10 \\
\hline Midwifery & 2 & 2 & 4 \\
\hline $\begin{array}{l}\text { Occupational } \\
\text { Therapy }\end{array}$ & 4 & 1 & 5 \\
\hline Multidisciplinary & 3 & 6 & 9 \\
\hline Mixed Stakeholders & 3 & 1 & 4 \\
\hline \multicolumn{4}{|c|}{ Date of publication } \\
\hline $2015-2017$ & 8 & 6 & 14 \\
\hline $2010-2014$ & 6 & 3 & 9 \\
\hline $2000-2009$ & 4 & 5 & 9 \\
\hline \multicolumn{4}{|c|}{ Country of Origin } \\
\hline United Kingdom & 7 & 3 & 10 \\
\hline USA & 3 & 5 & 8 \\
\hline Australia & 2 & 1 & 3 \\
\hline Sweden & 2 & - & 2 \\
\hline Japan & 2 & - & 2 \\
\hline Canada & 1 & 2 & 3 \\
\hline Multiple countries & 1 & - & 1 \\
\hline Jordan & - & 1 & 1 \\
\hline Norway & - & 1 & 1 \\
\hline New Zealand & - & 1 & 1 \\
\hline
\end{tabular}


37. Practitioner engagement by academic researchers

Table 5: Stages of the research process in which practitioners were engaged

\begin{tabular}{|c|c|c|c|}
\hline & $\begin{array}{c}\text { Evaluative } \\
\text { Papers } \\
(n=18)\end{array}$ & $\begin{array}{c}\text { Descriptive } \\
\text { papers } \\
(n=14)\end{array}$ & $\begin{array}{l}\text { Total } \\
(n=32)\end{array}$ \\
\hline \multicolumn{4}{|l|}{ Preparation } \\
\hline Prioritisation & 1 & - & 1 \\
\hline Question identification & - & - & - \\
\hline Protocol design & 2 & 2 & 4 \\
\hline \multicolumn{4}{|l|}{ Execution } \\
\hline Recruitment (screening, consent) & 5 & 4 & 9 \\
\hline Data collection tool design & - & - & - \\
\hline Intervention delivery & 6 & 1 & 7 \\
\hline Data collection & 3 & 3 & 6 \\
\hline Data analysis & - & 1 & 1 \\
\hline \multicolumn{4}{|l|}{ Translation } \\
\hline Dissemination & 1 & 3 & 4 \\
\hline Implementation activity & 5 & 3 & 8 \\
\hline Secondary data analysis & 1 & - & 1 \\
\hline
\end{tabular}


Table 6: Theoretical positions used to guide engagement of practitioners by academic researchers

\begin{tabular}{|c|c|}
\hline Evaluative Papers $(n=3)$ & Theoretical position \\
\hline Dufault and Sullivan (2000) & Collaborative Research Utilisation (CRU) approach \\
\hline Kothari, Birch \& Charles (2005) & Framework of interaction and research utilisation \\
\hline O’Reilly-de Brun et al. (2017) & Participatory and action learning research \\
\hline \multicolumn{2}{|l|}{ Descriptive Papers $(\mathrm{n}=8)$} \\
\hline Fitzgerald et al. (2003) & Collaborative Research \\
\hline Reed and Hocking (2013) & Collaborative Action research \\
\hline Harrison and Graham (2012) & $\begin{array}{l}\text { Integrated Knowledge Translation (IKT) } \\
\text { (Strategic alliance with practice community, } \\
\text { Research-practice partnership, participatory } \\
\text { research, collaborative research practice approach) }\end{array}$ \\
\hline Fredricks et al. (2015) & Integrated Knowledge Translation (IKT) \\
\hline Kresheh and Barclay (2007) & Practice-Research Engagement (PRE) \\
\hline Hummelvoll and Steverinsson (2005) & $\begin{array}{l}\text { Participatory research } \\
\text { Co-operative inquiry }\end{array}$ \\
\hline Burfold et al. (2015) & $\begin{array}{l}\text { Participatory research based on democratic dialogue } \\
\text { theory }\end{array}$ \\
\hline Sadler et al. (2017) & Co-production principles \\
\hline
\end{tabular}


39. Practitioner engagement by academic researchers

Figure 1: Results of the search process

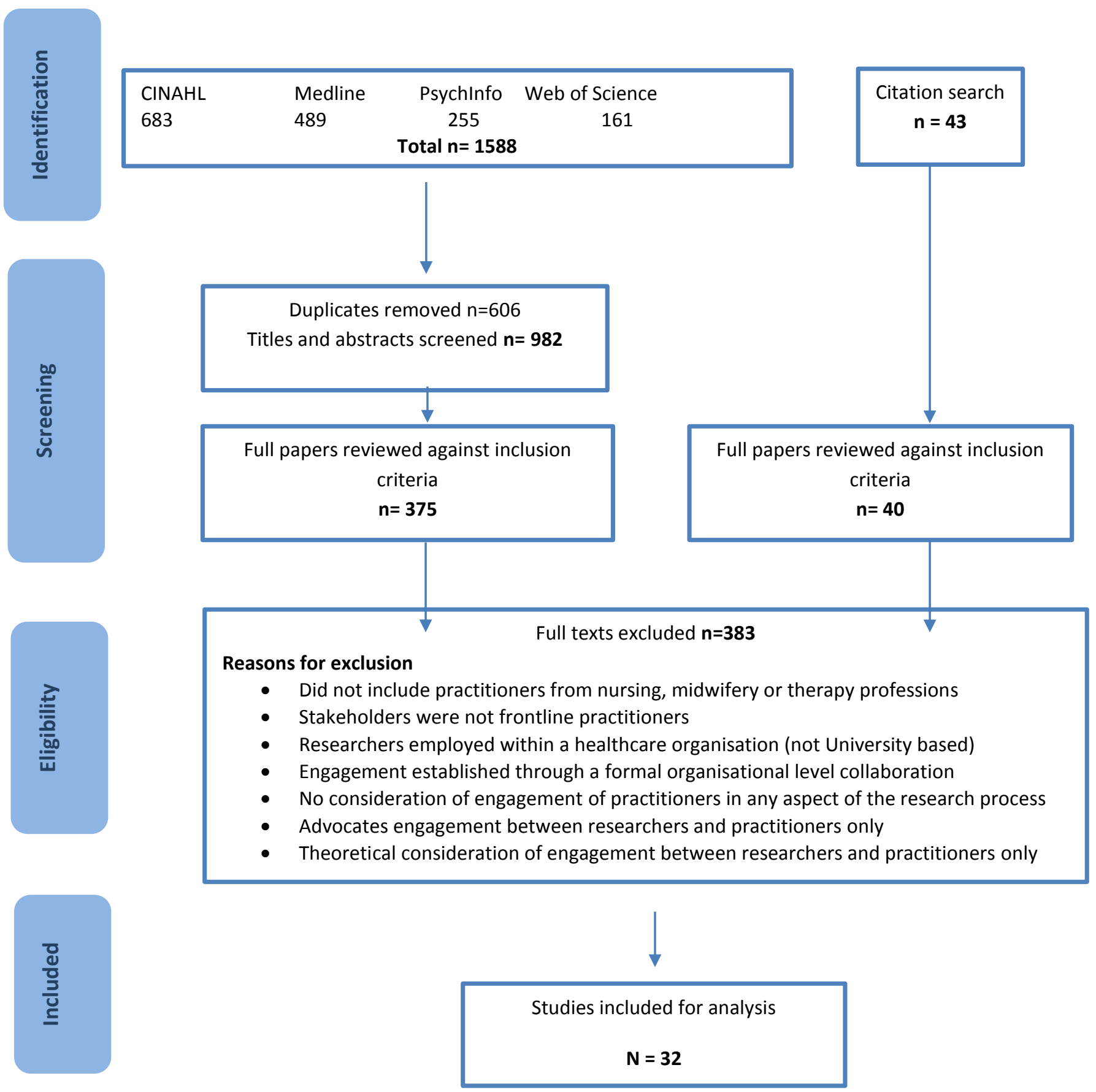


Figure 2: Frequency of terminology used within papers included in the review

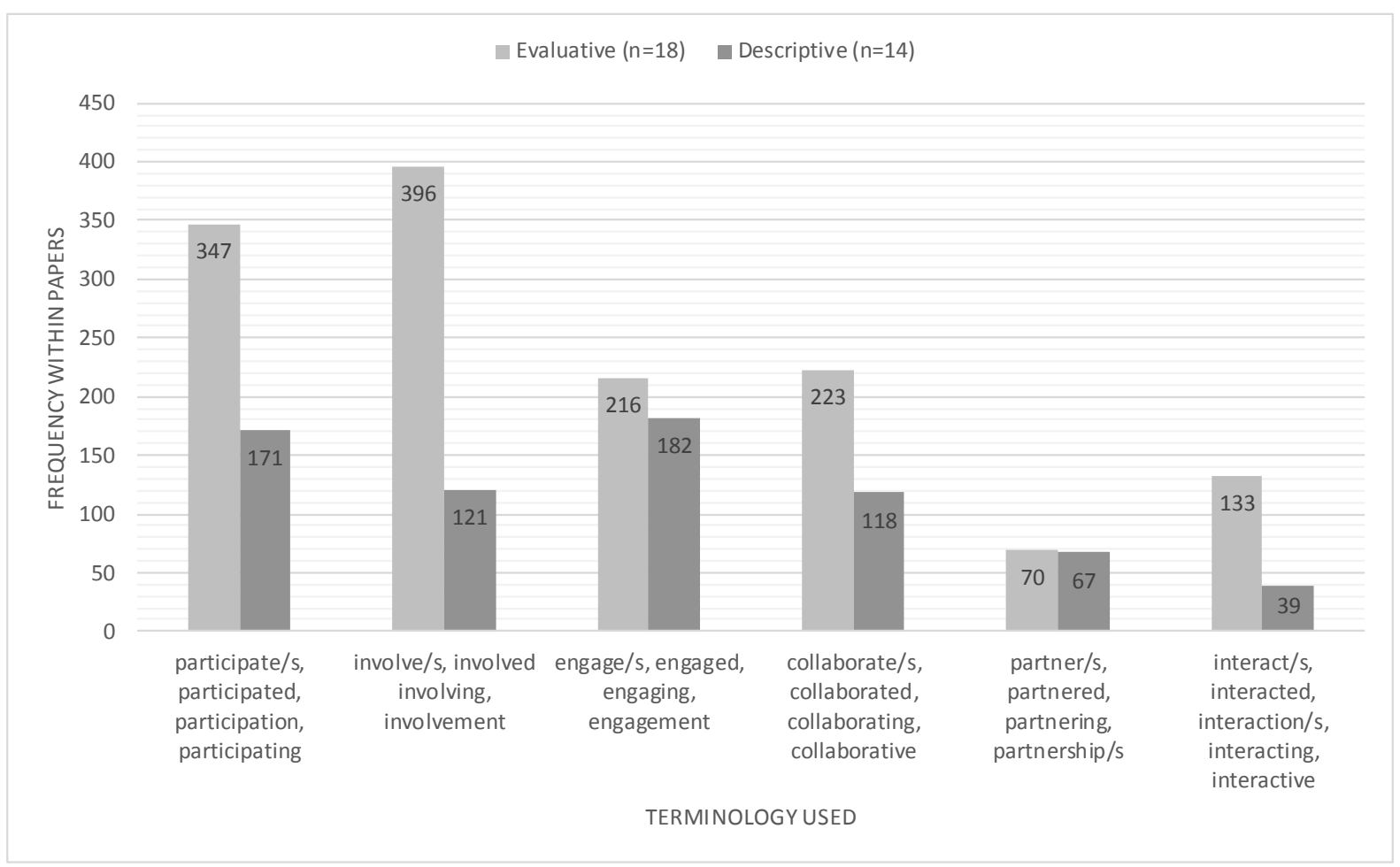




\begin{tabular}{|c|c|c|c|c|c|c|}
\hline $\begin{array}{l}\text { Authors/ Year } \\
\text { Country }\end{array}$ & $\begin{array}{c}\text { Study in which } \\
\text { engagement took } \\
\text { place }\end{array}$ & $\begin{array}{l}\text { Purpose of } \\
\text { paper }\end{array}$ & $\begin{array}{l}\text { Practitioners } \\
\text { Engaged and } \\
\text { Sample size }\end{array}$ & $\begin{array}{c}\text { Stages of research process } \\
\text { in which practitioners } \\
\text { engaged }\end{array}$ & $\begin{array}{c}\text { Method of evaluation of } \\
\text { engagement }\end{array}$ & $\begin{array}{l}\text { Focus of evaluation/type } \\
\text { of outcomes reported } \\
\text { from engagement }\end{array}$ \\
\hline $\begin{array}{l}\text { Andrew et al. (2013) } \\
\text { United Kingdom }\end{array}$ & $\begin{array}{l}\text { Development of the } \\
\text { Dignity Care } \\
\text { Pathway }\end{array}$ & $\begin{array}{l}\text { To discuss the } \\
\text { participation of } \\
\text { community } \\
\text { nurses in a } \\
\text { collaborative } \\
\text { research project } \\
\text { to implement a } \\
\text { palliative care } \\
\text { intervention in } \\
\text { practice }\end{array}$ & Nurses $(\mathrm{n}=25)$ & $\begin{array}{l}\text { Translation } \\
\text { Implementation of the } \\
\text { pathway in to routine } \\
\text { practice }\end{array}$ & $\begin{array}{l}\text { Qualitative } \\
\text { Focus groups (before and } \\
\text { after use of the pathway) }\end{array}$ & $\begin{array}{l}\text { Evaluation of experiences } \\
\text { of community nurses } \\
\text { Practical challenges of } \\
\text { participating in a research } \\
\text { project }\end{array}$ \\
\hline $\begin{array}{l}\text { Boase, Kim, Craven, \& } \\
\text { Cohn. (2012) } \\
\text { United Kingdom }\end{array}$ & $\begin{array}{l}\text { A multi-site } \\
\text { randomised } \\
\text { controlled } \\
\text { intervention trial to } \\
\text { evaluate the } \\
\text { efficacy of a theory- } \\
\text { based intervention } \\
\text { to support patients } \\
\text { in taking their } \\
\text { medication as } \\
\text { prescribed } \\
\text { compared with } \\
\text { standard care }\end{array}$ & $\begin{array}{l}\text { To explore the } \\
\text { experiences of } \\
\text { practice nurses } \\
\text { delivering a } \\
\text { complex research } \\
\text { intervention in an } \\
\text { exploratory } \\
\text { randomized } \\
\text { controlled trial in } \\
\text { primary care }\end{array}$ & Nurses $(n=14)$ & $\begin{array}{l}\text { Execution } \\
\text { Delivery of study } \\
\text { intervention }\end{array}$ & $\begin{array}{l}\text { Qualitative } \\
\text { Semi-structured interviews }\end{array}$ & $\begin{array}{l}\text { Evaluation of experiences } \\
\text { of nurses } \\
\text { Practical challenges of } \\
\text { involvement in a research } \\
\text { project }\end{array}$ \\
\hline Bullen et al. (2014) & $\begin{array}{l}\text { To examine impact } \\
\text { on patient outcomes } \\
\text { of providing } \\
\text { emergency } \\
\text { medication kits to } \\
\text { home dwelling } \\
\text { palliative care } \\
\text { patients }\end{array}$ & $\begin{array}{l}\text { To describe the } \\
\text { process of } \\
\text { implementing a } \\
\text { clinical research } \\
\text { project in } \\
\text { collaboration } \\
\text { with clinicians in } \\
\text { a palliative care } \\
\text { community team }\end{array}$ & $\begin{array}{l}\text { Multidisciplinary palliative care } \\
\text { community team (n=NR) } \\
\text { (includes nurses) }\end{array}$ & $\begin{array}{l}\text { Execution } \\
\text { Recruitment } \\
\begin{array}{l}\text { Development of data } \\
\text { collection tool }\end{array} \\
\begin{array}{l}\text { Delivery of study } \\
\text { intervention }\end{array}\end{array}$ & $\begin{array}{l}\text { Qualitative } \\
\text { Written observations by } \\
\text { each investigator (examined } \\
\text { for recurring thematic } \\
\text { patterns) }\end{array}$ & $\begin{array}{l}\text { Identify challenges } \\
\text { and/or enablers }\end{array}$ \\
\hline Di Bona et al. (2017) & $\begin{array}{l}\text { Valuing Active Life } \\
\text { in Dementia }\end{array}$ & $\begin{array}{l}\text { To improve } \\
\text { understanding of }\end{array}$ & Occupational Therapists $(\mathrm{n}=28)$ & Execution & Qualitative & $\begin{array}{l}\text { Identify challenges } \\
\text { and/or enablers of }\end{array}$ \\
\hline
\end{tabular}




\begin{tabular}{|c|c|c|c|c|c|c|}
\hline United Kingdom & $\begin{array}{l}\text { (VALID) research } \\
\text { programme; to } \\
\text { develop and } \\
\text { evaluate a } \\
\text { community } \\
\text { occupational } \\
\text { therapy programme } \\
\text { for people living } \\
\text { with dementia }\end{array}$ & $\begin{array}{l}\text { the challenges } \\
\text { and enablers } \\
\text { experienced by } \\
\text { occupational } \\
\text { therapists who } \\
\text { deliver an } \\
\text { intervention } \\
\text { within a research } \\
\text { study }\end{array}$ & & $\begin{array}{l}\text { Participant recruitment } \\
\text { Delivery of study } \\
\text { intervention } \\
\text { Data collection }\end{array}$ & Focus groups & $\begin{array}{l}\text { delivering an intervention } \\
\text { within a research study }\end{array}$ \\
\hline $\begin{array}{l}\text { Dufault \& Sullivan } \\
(2000) \\
\text { USA }\end{array}$ & $\begin{array}{l}\text { Pain management } \\
\text { To examine } \\
\text { guidelines and } \\
\text { recent innovations } \\
\text { of research in pain } \\
\text { management and } \\
\text { generate a standard } \\
\text { of care based on } \\
\text { that research }\end{array}$ & $\begin{array}{l}\text { To answer 'does } \\
\text { involving } \\
\text { clinicians in } \\
\text { generating and } \\
\text { evaluating a } \\
\text { research-based } \\
\text { pain management } \\
\text { standard lead to } \\
\text { changes in } \\
\text { practice and } \\
\text { improve } \\
\text { outcomes for } \\
\text { patients'? }\end{array}$ & $\begin{array}{l}\text { Nurses }(\mathrm{n}=38) \\
\text { Physiotherapist }(\mathrm{n}=1)\end{array}$ & $\begin{array}{l}\text { Translation } \\
\text { Implementation (research- } \\
\text { based practice standard) } \\
\text { Dissemination (conference } \\
\text { presentation) }\end{array}$ & $\begin{array}{l}\text { Quantitative } \\
\text { A 2-group, pre-test- } \\
\text { intervention-post-test, } \\
\text { quasi-experimental clinical } \\
\text { trial } \\
\text { Clinical outcomes }\end{array}$ & $\begin{array}{l}\text { Determine if involving } \\
\text { practitioners led to } \\
\text { changes in practice and } \\
\text { patient outcomes }\end{array}$ \\
\hline $\begin{array}{l}\text { Dyson \& Dyson (2014) } \\
\text { United Kingdom }\end{array}$ & $\begin{array}{l}\text { Ethnicity Questions } \\
\text { and Antenatal } \\
\text { Screening for } \\
\text { Sickle } \\
\text { Cell/Thalassaemia } \\
\text { Randomised } \\
\text { Controlled Trial } \\
\text { (RCT) }\end{array}$ & $\begin{array}{l}\text { To examine the } \\
\text { role of midwives } \\
\text { in a RCT }\end{array}$ & Midwives $(\mathrm{n}=62)$ & $\begin{array}{l}\text { Execution } \\
\text { Collecting and entering data }\end{array}$ & $\begin{array}{l}\text { Qualitative } \\
\text { Questionnaires; notes at } \\
\text { workshops; notes written by } \\
\text { the authors after field } \\
\text { encounters; review of letters } \\
\text { and emails pertaining to the } \\
\text { project }\end{array}$ & $\begin{array}{l}\text { Determine level of } \\
\text { engagement in research } \\
\text { tasks }\end{array}$ \\
\hline $\begin{array}{l}\text { Eriksson, Tham, \& } \\
\text { Guidetti (2013) } \\
\text { Sweden }\end{array}$ & $\begin{array}{l}\text { Evaluation of a new } \\
\text { Client Centred Self- } \\
\text { Care Intervention } \\
\text { (CCSCI) for } \\
\text { persons with stroke } \\
\text { in a Randomised } \\
\text { Controlled Trial } \\
\text { (RCT) (Pilot study) }\end{array}$ & $\begin{array}{l}\text { To describe } \\
\text { occupational } \\
\text { therapists' } \\
\text { expectations and } \\
\text { experiences of } \\
\text { integrating a new } \\
\text { intervention } \\
\text { programme }\end{array}$ & Occupational Therapists $(\mathrm{n}=6)$ & $\begin{array}{l}\text { Execution } \\
\text { Delivery of intervention }\end{array}$ & $\begin{array}{l}\text { Qualitative } \\
\text { Grounded Theory } \\
\text { Paired and group interview } \\
\text { before and after } \\
\text { intervention delivery }\end{array}$ & $\begin{array}{l}\text { Evaluate experiences of } \\
\text { occupational therapists }\end{array}$ \\
\hline
\end{tabular}




\begin{tabular}{|c|c|c|c|c|c|c|}
\hline & & $\begin{array}{l}\text { within an RCT } \\
\text { pilot study in } \\
\text { collaboration } \\
\text { with a researcher }\end{array}$ & & & $\begin{array}{l}\text { Written reflection protocols } \\
\text { collected from researcher } \\
\text { and participating } \\
\text { occupational therapists' }\end{array}$ & \\
\hline $\begin{array}{l}\text { Eriksson et al. (2017) } \\
\text { Sweden }\end{array}$ & $\begin{array}{l}\text { Randomised } \\
\text { Controlled Trial } \\
\text { (RCT); Life after } \\
\text { stroke }\end{array}$ & $\begin{array}{l}\text { To identify and } \\
\text { describe the } \\
\text { process of how } \\
\text { occupational } \\
\text { therapists in } \\
\text { collaboration } \\
\text { with a researcher } \\
\text { implemented a } \\
\text { client-centred } \\
\text { Activities of } \\
\text { Daily Living } \\
\text { (ADL) } \\
\text { intervention for } \\
\text { persons with } \\
\text { stroke }\end{array}$ & Occupational Therapists $(\mathrm{n}=33)$ & $\begin{array}{l}\text { Translation } \\
\text { Implementation of } \\
\text { intervention }\end{array}$ & $\begin{array}{l}\text { Qualitative longitudinal } \\
\text { data collection } \\
\text { Focus groups }(2,6 \& 12 \\
\text { months }\end{array}$ & $\begin{array}{l}\text { Evaluate experiences of } \\
\text { occupational therapists }\end{array}$ \\
\hline $\begin{array}{l}\text { Finlayson et al. (2005) } \\
\text { USA }\end{array}$ & $\begin{array}{l}\text { Randomised } \\
\text { Controlled Trial } \\
\text { (RCT) to examine } \\
\text { the effects of a 6- } \\
\text { week educational } \\
\text { energy conservation } \\
\text { course for people } \\
\text { living with Multiple } \\
\text { Sclerosis }\end{array}$ & $\begin{array}{l}\text { To ask } \\
\text { occupational } \\
\text { therapists who } \\
\text { were involved in } \\
\text { an RCT to reflect } \\
\text { on experiences } \\
\text { and whether these } \\
\text { influenced how } \\
\text { they think about } \\
\text { or undertake their } \\
\text { practice }\end{array}$ & Occupational Therapists $(\mathrm{n}=8)$ & $\begin{array}{l}\text { Execution } \\
\text { Delivery of intervention, } \\
\text { screening of study } \\
\text { participants } \\
\text { (involvement ranged from } \\
30 \text { to } 100 \text { hours) }\end{array}$ & $\begin{array}{l}\text { Qualitative } \\
\text { Written questionnaire using } \\
\text { open ended questions }\end{array}$ & $\begin{array}{l}\text { Evaluate experiences of } \\
\text { occupational therapists }\end{array}$ \\
\hline $\begin{array}{l}\text { Fujimoto et al. (2015) } \\
\text { Japan }\end{array}$ & Multiple projects & $\begin{array}{l}\text { To investigate the } \\
\text { degree of } \\
\text { collaboration } \\
\text { between } \\
\text { practitioners and } \\
\text { researchers } \\
\text { through research } \\
\text { papers related to } \\
\text { the } \\
\text { implementation } \\
\text { of electrical }\end{array}$ & $\begin{array}{l}\text { Research papers }(\mathrm{n}=165) \\
\text { Rehab (Occupational Therapists } \\
\text { \& Physiotherapist) }\end{array}$ & $\begin{array}{l}\text { Translation } \\
\text { Dissemination }\end{array}$ & $\begin{array}{l}\text { Literature based } \\
\text { Systematic Review }\end{array}$ & $\begin{array}{l}\text { Determine level of } \\
\text { engagement of } \\
\text { practitioners }\end{array}$ \\
\hline
\end{tabular}




\begin{tabular}{|c|c|c|c|c|c|c|}
\hline & & $\begin{array}{l}\text { stimulation }(\mathrm{ES}) \\
\text { for stroke } \\
\text { patients. }\end{array}$ & & & & \\
\hline $\begin{array}{l}\text { Ishimaru et al. (2016) } \\
\text { Japan }\end{array}$ & $\begin{array}{l}\text { Multiple } \\
\text { collaborative } \\
\text { projects }\end{array}$ & $\begin{array}{l}\text { To evaluate the } \\
\text { effects of } \\
\text { participation in } \\
\text { (multiple) } \\
\text { collaborative } \\
\text { research-based } \\
\text { project }\end{array}$ & Nurses $(n=33)$ & Various (multiple projects) & $\begin{array}{l}\text { Qualitative } \\
\text { Quantitative } \\
\text { Survey (n=25) } \\
\text { Group interviews }(n=15)\end{array}$ & $\begin{array}{l}\text { Evaluate experiences of } \\
\text { nurses }\end{array}$ \\
\hline $\begin{array}{l}\text { Khodyakov et al. } \\
\text { (2017) } \\
\text { (Patient Centred } \\
\text { Outcomes Research } \\
\text { Institute; PCORI) } \\
\text { USA }\end{array}$ & $\begin{array}{l}\text { Comparative } \\
\text { analysis of } \\
\text { stakeholder } \\
\text { experiences with an } \\
\text { online approach to } \\
\text { prioritizing patient- } \\
\text { centered research } \\
\text { topics }\end{array}$ & $\begin{array}{l}\text { To compare } \\
\text { patients and } \\
\text { professionals' } \\
\text { experiences with } \\
\text { OMD (Online } \\
\text { Modified Delphi } \\
\text { panels) conducted } \\
\text { to identify } \\
\text { research priorities }\end{array}$ & $\begin{array}{l}\text { Patients }(\mathrm{n}=133) \\
\text { Professionals }(\mathrm{n}=159) \\
\text { (physicians, nurses, dieticians } \\
\text { and other clinicians) }\end{array}$ & $\begin{array}{l}\text { Preparation } \\
\text { Prioritisation of research } \\
\text { topics }\end{array}$ & $\begin{array}{l}\text { Quantitative } \\
\text { Participant experience } \\
\text { survey using Likert scales }\end{array}$ & $\begin{array}{l}\text { Evaluate experiences of } \\
\text { using a specific } \\
\text { engagement strategy }\end{array}$ \\
\hline $\begin{array}{l}\text { Kothari, Birch \& } \\
\text { Charles (2005) } \\
\text { Canada }\end{array}$ & $\begin{array}{l}\text { Commissioned } \\
\text { report on breast } \\
\text { health practices } \\
\text { report }\end{array}$ & $\begin{array}{l}\text { To determine if } \\
\text { interaction } \\
\text { between } \\
\text { researchers and } \\
\text { users promoted } \\
\text { the utilisation of } \\
\text { research findings } \\
\\
\text { Public Health } \\
\text { Unit (PHU) } \\
\text { teams involved in } \\
\text { assisting } \\
\text { researchers with a } \\
\text { report based on } \\
\text { secondary } \\
\text { analysis of } \\
\text { existing data }\end{array}$ & $\begin{array}{l}6 \text { Public Health Unit breast care } \\
\text { teams } \\
\text { (Nurses, manager, admin } \\
\text { support) }\end{array}$ & $\begin{array}{l}\text { Translation } \\
\text { Implementation of breast } \\
\text { health practices report }\end{array}$ & $\begin{array}{l}\text { Qualitative } \\
\text { Group interviews }\end{array}$ & $\begin{array}{l}\text { Determine if utilisation of } \\
\text { findings was promoted }\end{array}$ \\
\hline $\begin{array}{l}\text { O'Reilly-de Brun et al. } \\
\text { (2017) }\end{array}$ & $\begin{array}{l}\text { RESTORE } \\
\text { (Research into } \\
\text { Implementation } \\
\end{array}$ & $\begin{array}{l}\text { To explore } \\
\text { stakeholders' and } \\
\text { researchers' }\end{array}$ & $\begin{array}{l}78 \text { stakeholders (8 Nurses) (Plus } \\
\text { GPs, service providers, service } \\
\text { planners) }\end{array}$ & Translation & Qualitative & $\begin{array}{l}\text { Evaluate use of a specific } \\
\text { engagement strategy }\end{array}$ \\
\hline
\end{tabular}




\begin{tabular}{|c|c|c|c|c|c|c|}
\hline International & $\begin{array}{l}\text { Strategies to } \\
\text { Support } \\
\text { Patients of } \\
\text { Different Origins } \\
\text { and Language } \\
\text { Background in a } \\
\text { Variety of } \\
\text { European Primary } \\
\text { Care Settings) }\end{array}$ & $\begin{array}{l}\text { experiences of } \\
\text { Participatory } \\
\text { Learning and } \\
\text { Action (PLA) } \\
\text { techniques for } \\
\text { data generation } \\
\text { and co-analysis }\end{array}$ & & $\begin{array}{l}\text { Implementation (of } \\
\text { guidelines and training } \\
\text { initiatives (GTIs)) }\end{array}$ & $\begin{array}{l}\text { Participatory speed } \\
\text { evaluations }\end{array}$ & \\
\hline $\begin{array}{l}\text { Pollock et al. (2015) } \\
\text { United Kingdom }\end{array}$ & $\begin{array}{l}\text { Updating of a } \\
\text { Cochrane review of } \\
\text { physiotherapy } \\
\text { treatment following } \\
\text { a stroke }\end{array}$ & $\begin{array}{l}\text { To explore the } \\
\text { perceived impact } \\
\text { of involvement of } \\
\text { users in updating } \\
\text { a Cochrane } \\
\text { review }\end{array}$ & $\begin{array}{l}\text { Physiotherapists }(\mathrm{n}=9 \text { ) } \\
\text { (Plus } 4 \text { service users) }\end{array}$ & $\begin{array}{l}\text { Translation } \\
\text { Categorisation of categories } \\
\text { within systematic review, } \\
\text { inclusion criteria, consensus } \\
\text { on key message of review }\end{array}$ & $\begin{array}{l}\text { Quantitative } \\
\text { Brief evaluation Likert } \\
\text { scale and open comments } \\
\text { (stakeholder perspective } \\
\mathrm{n}=9 \text { ) } \\
\text { Description of perceived } \\
\text { impact of involvement from } \\
\text { researcher perspective }\end{array}$ & $\begin{array}{l}\text { Explore perceived impact } \\
\text { of involvement of users } \\
\text { in updating a Cochrane } \\
\text { review }\end{array}$ \\
\hline $\begin{array}{l}\text { Potter, Dale, \& } \\
\text { Caramlau (2009) } \\
\text { United Kingdom }\end{array}$ & $\begin{array}{l}\text { Randomised } \\
\text { Controlled Trial } \\
\text { (RCT) to promote } \\
\text { adherence to } \\
\text { treatment and } \\
\text { increase feelings } \\
\text { of self-efficacy for } \\
\text { people with type } 2 \\
\text { diabetes through the } \\
\text { provision of } \\
\text { telephone } \\
\text { support. }\end{array}$ & $\begin{array}{l}\text { To explore } \\
\text { practice nurses' } \\
\text { experience of } \\
\text { participating } \\
\text { in research and to } \\
\text { learn how this } \\
\text { may have } \\
\text { influenced } \\
\text { recruitment for a } \\
\text { primary } \\
\text { care-based RCT }\end{array}$ & Nurses $(n=10)$ & $\begin{array}{l}\text { Execution } \\
\text { Participant recruitment }\end{array}$ & $\begin{array}{l}\text { Qualitative } \\
\text { Semi-structured interviews }\end{array}$ & $\begin{array}{l}\text { Explore nurses' } \\
\text { experiences in their role } \\
\text { as a recruiter and their } \\
\text { perception of factors } \\
\text { which influenced } \\
\text { recruitment rates }\end{array}$ \\
\hline $\begin{array}{l}\text { Stockwell-Smith et al. } \\
\text { (2015) } \\
\text { Australia }\end{array}$ & $\begin{array}{l}\text { Mixed methods } \\
\text { study to establish } \\
\text { the effectiveness of } \\
\text { working with } \\
\text { dementia dyads } \\
\text { (person with } \\
\text { dementia and } \\
\text { family caregiver) in } \\
\text { the early stages of } \\
\text { dementia }\end{array}$ & $\begin{array}{l}\text { To explore the } \\
\text { practical aspects } \\
\text { of psychosocial } \\
\text { intervention } \\
\text { implementation } \\
\text { and acceptance to } \\
\text { determine the } \\
\text { feasibility of } \\
\text { using a } \\
\text { community aged }\end{array}$ & $\begin{array}{l}\text { Registered nurses }(\mathrm{n}=3) \text { and } \\
\text { Personal Care Workers }(\mathrm{n}=20) \\
\text { NB: only one registered nurse } \\
\text { and } 6 \text { Personal Care Workers } \\
\text { took part in the post- } \\
\text { intervention interviews }\end{array}$ & $\begin{array}{l}\text { Execution } \\
\text { Delivery of intervention }\end{array}$ & $\begin{array}{l}\text { Qualitative } \\
\text { Semi-structured interviews }\end{array}$ & $\begin{array}{l}\text { Identify challenges } \\
\text { and/or enablers of staff } \\
\text { participation and } \\
\text { delivering study } \\
\text { intervention }\end{array}$ \\
\hline
\end{tabular}




\begin{tabular}{|c|c|c|c|c|c|c|}
\hline & & $\begin{array}{l}\text { care practitioner } \\
\text { workforce to } \\
\text { deliver the } \\
\text { (study) } \\
\text { intervention }\end{array}$ & & & & \\
\hline $\begin{array}{l}\text { Stuart et al. (2015) } \\
\text { United Kingdom }\end{array}$ & $\begin{array}{l}\text { Multisite } \\
\text { Randomised } \\
\text { Controlled Trial } \\
\text { aimed to examine if } \\
\text { provision of Group } \\
\text { Family Nurse } \\
\text { Partnership (gFNP) } \\
\text { compared to routine } \\
\text { antenatal and } \\
\text { postnatal services } \\
\text { could reduce risk } \\
\text { factors for child } \\
\text { maltreatment }\end{array}$ & $\begin{array}{l}\text { To investigate the } \\
\text { perceptions of } \\
\text { community } \\
\text { midwives about } \\
\text { their role in } \\
\text { identifying } \\
\text { potential } \\
\text { participants in an } \\
\text { RCT }\end{array}$ & $\begin{array}{l}\text { Midwives ( } 13 \text { out of a possible } \\
\text { 304) }\end{array}$ & $\begin{array}{l}\text { Execution } \\
\text { Identification and } \\
\text { recruitment of participants }\end{array}$ & $\begin{array}{l}\text { Qualitative } \\
\text { Semi-structured interviews }\end{array}$ & $\begin{array}{l}\text { Identify midwives' } \\
\text { perceptions of practical } \\
\text { challenges to their } \\
\text { research role }\end{array}$ \\
\hline
\end{tabular}

Note: $N R=$ Not reported 


\begin{tabular}{|c|c|c|c|c|c|}
\hline $\begin{array}{l}\text { Author } \\
\text { Country }\end{array}$ & $\begin{array}{l}\text { Study in which engagement } \\
\text { took place }\end{array}$ & Purpose of paper & $\begin{array}{c}\text { Practitioners } \\
\text { engaged in study }\end{array}$ & $\begin{array}{l}\text { Stage(s) of research process in } \\
\text { which practitioners engaged }\end{array}$ & Outcomes described \\
\hline $\begin{array}{l}\text { Albers \& } \\
\text { Sedler (2004) } \\
\text { USA }\end{array}$ & $\begin{array}{l}\text { Randomised Controlled Trial; } \\
\text { methods to lower genital tract } \\
\text { trauma }\end{array}$ & $\begin{array}{l}\text { To report on pros and cons of } \\
\text { involvement in research }\end{array}$ & Midwives $(\mathrm{n}=12)$ & $\begin{array}{l}\text { Execution } \\
\text { Performed pilot studies, tested data } \\
\text { form, collected data, reviewed data } \\
\text { analyses, planned new projects }\end{array}$ & Benefits and challenges \\
\hline $\begin{array}{l}\text { Burford, Park, } \\
\text { DawDa, \& } \\
\text { Burns (2015) } \\
\text { Australia }\end{array}$ & $\begin{array}{l}\text { Exploratory study that introduces } \\
\text { mobile tablet devices for the } \\
\text { management of type } 2 \text { diabetes }\end{array}$ & $\begin{array}{l}\text { To report on the participatory } \\
\text { research design of the study }\end{array}$ & $\begin{array}{l}\text { GP, Practice Nurse, } \\
\text { Dieticians, } \\
\text { Psychologists }(n=N R)\end{array}$ & $\begin{array}{l}\text { Preparation, Execution } \\
\text { Contributed to study 'intervention' } \\
\text { through facilitated workshops to } \\
\text { elicit knowledge and opinions }\end{array}$ & $\begin{array}{l}\text { Authors acknowledged the positive } \\
\text { influence of healthcare } \\
\text { practitioners on the design } \\
\text { outcomes of this study }\end{array}$ \\
\hline $\begin{array}{l}\text { Campbell et } \\
\text { al. (2015) }\end{array}$ & $\begin{array}{l}\text { Stroke rehabilitation clinical } \\
\text { trials }\end{array}$ & $\begin{array}{l}\text { Describes experiences of } \\
\text { researchers who became a } \\
\text { nearly constant presence in the } \\
\text { stroke rehabilitation unit to } \\
\text { overcome practical and } \\
\text { methodological challenges in } \\
\text { designing and conducting } \\
\text { inpatient stroke rehabilitation } \\
\text { clinical trials }\end{array}$ & $\begin{array}{l}\text { Rehabilitation } \\
\text { professionals ( } \mathrm{n}=\mathrm{NR})\end{array}$ & $\begin{array}{l}\text { Execution } \\
\text { Clinicians: sought out researchers } \\
\text { for scheduling concerns and to alert } \\
\text { researchers to changes in patients' } \\
\text { condition that might impact research } \\
\text { assessments } \\
\text { offered perspectives regarding } \\
\text { variables of interest and operational } \\
\text { considerations of conducting studies } \\
\text { Researchers refined research } \\
\text { procedures to accommodate the } \\
\text { clinical team's concerns } \\
\text { authors on manuscripts } \\
\text { Researchers mentored clinical staff } \\
\text { seeking research grants, provided } \\
\text { continuing education programs, } \\
\text { presented at unit journal clubs }\end{array}$ & $\begin{array}{l}\text { Researchers perceptions of benefits } \\
\text { to participants, clinicians and } \\
\text { research team }\end{array}$ \\
\hline $\begin{array}{l}\text { Fitzgerald et } \\
\text { al. (2003) }\end{array}$ & $\begin{array}{l}\text { Role Modelling Interventions for } \\
\text { Family Boundary Ambiguity in } \\
\text { are Paeditaric Intensive Care } \\
\text { Unit (PICU) }\end{array}$ & $\begin{array}{l}\text { Discusses two paediatric } \\
\text { critical care nurse specialists } \\
\text { participation in a collaborative }\end{array}$ & $\begin{array}{l}\text { Clinical Nurse } \\
\text { Specialists }(n=2)\end{array}$ & $\begin{array}{l}\text { Preparation, Execution, Translation } \\
\text { CNS "Co-Principal Investigator } \\
\text { involved in all aspects of the study" }\end{array}$ & $\begin{array}{l}\text { Challenges of implementing } \\
\text { clinical research role } \\
\text { Benefits of using a collaborative } \\
\text { research model }\end{array}$ \\
\hline
\end{tabular}




\begin{tabular}{|c|c|c|c|c|c|}
\hline & $\begin{array}{l}\text { Experimental and } \\
\text { phenomenological design }\end{array}$ & $\begin{array}{l}\text { research team led by university } \\
\text { faculty }\end{array}$ & & $\begin{array}{l}\text { Conceptualisation, ethics approvals, } \\
\text { presentation to funding committee, } \\
\text { co-managed budget, ongoing liaison } \\
\text { with nursing staff, study } \\
\text { intervention, distributed } \\
\text { questionnaires, abstract writing, } \\
\text { manuscript preparation poster and } \\
\text { paper presentations }\end{array}$ & \\
\hline $\begin{array}{l}\text { Fredricks et } \\
\text { al. (2015) } \\
\text { Canada }\end{array}$ & $\begin{array}{l}\text { Randomised Controlled Trial to } \\
\text { evaluate a web-based patient } \\
\text { education intervention }\end{array}$ & $\begin{array}{l}\text { To describe the process of } \\
\text { using an Integrated Knowledge } \\
\text { Translation approach to design } \\
\text { a research study } \\
\text { (prospective) }\end{array}$ & $\begin{array}{l}\text { Lead nurse }(\mathrm{n}=1) \\
\text { other nurses }(\mathrm{n}=\mathrm{NR})\end{array}$ & $\begin{array}{l}\text { Preparation, Execution, Translation } \\
\text { Lead nurse; Protocol design } \\
\text { consulted to ensure that the question } \\
\text { targeted the intended context and } \\
\text { could be transferred to similar } \\
\text { audiences across similar settings } \\
\text { determine appropriate research } \\
\text { question and study methodology } \\
\text { ongoing feedback as the study is } \\
\text { being designed and/or implemented } \\
\text { Nurses; will interpret results, develop } \\
\text { recommendations, help to identify } \\
\text { audiences for dissemination, draft } \\
\text { systematic review, submit of grant } \\
\text { proposals, provide insight into the } \\
\text { knowledge needs of other users } \\
\text { assist in refining the grant proposals } \\
\text { and manuscripts to maximize the } \\
\text { likelihood that the research results } \\
\text { will be easily implemented into } \\
\text { practice. }\end{array}$ & $\begin{array}{l}\text { Planning to obtain: } \\
\text { Feedback from nurses regarding } \\
\text { amount of time involved in the } \\
\text { study, perception of factors that } \\
\text { facilitated or interfered with } \\
\text { participation, or affected the KT } \\
\text { process, data related to reasons for } \\
\text { knowledge user attrition, } \\
\text { effectiveness of the knowledge user } \\
\text { recruitment strategy and utility and } \\
\text { feasibility of the knowledge user } \\
\text { screening procedure }\end{array}$ \\
\hline $\begin{array}{l}\text { Gettrust et al. } \\
\text { (2016) } \\
\text { USA }\end{array}$ & $\begin{array}{l}\text { Study to evaluate the feasibility } \\
\text { of an educational intervention } \\
\text { that prepared family carers to } \\
\text { take action when delirium } \\
\text { symptom observed in older } \\
\text { adults }\end{array}$ & $\begin{array}{l}\text { To describe the process of } \\
\text { exploring and implementing an } \\
\text { academic-clinical study } \\
\text { engaging nursing staff in } \\
\text { research }\end{array}$ & $\begin{array}{l}\text { Orthopaedic Clinic } \\
\text { Nurses (n=NR) }\end{array}$ & $\begin{array}{l}\text { Preparation, Execution, Translation } \\
\text { Engaged with a Clinical Nurse } \\
\text { Specialist in order to obtain buy in } \\
\text { and sustain engagement with } \\
\text { frontline nurses } \\
\text { Clinical Nurse Specialist linked the } \\
\text { academic and clinical partners; work }\end{array}$ & Described process \\
\hline
\end{tabular}




\begin{tabular}{|c|c|c|c|c|c|}
\hline & & & & $\begin{array}{l}\text { with clinic nurses to review aims of } \\
\text { study, map process for scheduling } \\
\text { clinic appointments along with time } \\
\text { frame for study, obtained 'buy-in' } \\
\text { from staff, sustained clinic staff } \\
\text { engagement with study } \\
\text { Clinic staff; identification of } \\
\text { potential study participants, data } \\
\text { collection, integrated study into their } \\
\text { daily workload }\end{array}$ & \\
\hline $\begin{array}{l}\text { Harrison \& } \\
\text { Graham } \\
(2012) \\
\text { Canada }\end{array}$ & $\begin{array}{l}\text { Evidence-based practice and } \\
\text { implementation for care } \\
\text { improvement in wound care } \\
\text { management }\end{array}$ & $\begin{array}{l}\text { To describe practical } \\
\text { experiences as researchers of } \\
\text { working at point of care and } \\
\text { how research can be used to } \\
\text { facilitate the implementation of } \\
\text { evidence }\end{array}$ & $\begin{array}{l}\text { Nurses ( } \mathrm{n}=\mathrm{NR}) \\
\text { Physicians }\end{array}$ & $\begin{array}{l}\text { Translation } \\
\text { Issue clarification, question } \\
\text { identification, analysis of available } \\
\text { research, implementation (of } \\
\text { evidence-based guidelines) }\end{array}$ & $\begin{array}{l}\text { Lessons learnt } \\
\text { Reflection on clinical } \\
\text { developments } \\
\text { Brief report of a 1-year pre-post } \\
\text { evaluation to measure patient and } \\
\text { system outcomes }\end{array}$ \\
\hline $\begin{array}{l}\text { Hummelvoll } \\
\& \\
\text { Steverinsson } \\
(2005) \\
\text { Norway }\end{array}$ & $\begin{array}{l}\text { Action research Ethnographic } \\
\text { study with use of co-operative } \\
\text { inquiry design of the Project } \\
\text { Teaching Ward }\end{array}$ & $\begin{array}{l}\text { To reflect upon experiences of } \\
\text { using co-operative inquiry in } \\
\text { an action research project }\end{array}$ & $\begin{array}{l}\text { Nurses }(\mathrm{n}=22), \\
\text { Occupational } \\
\text { Therapist }(\mathrm{n}=1), \mathrm{SW} \\
(\mathrm{n}=1), \text { Doctors }(\mathrm{n}=2) \\
\text { Charge nurse } \\
\text { ward staff }(\mathrm{n}=\mathrm{NR})\end{array}$ & $\begin{array}{l}\text { Preparation, Execution, Translation } \\
\text { Research planning and actions } \\
\text { carried out in collaboration } \\
\text { Actively participated in deciding on } \\
\text { the themes for inquiry, preliminary } \\
\text { reports presented to co-researchers to } \\
\text { validate the findings and to establish } \\
\text { their clinical relevance } \\
\text { Experienced nurse appointed as co- } \\
\text { ordinator to mediate between the } \\
\text { staff, seminars and weekly dialogical } \\
\text { teaching sessions; report research } \\
\text { progress and setbacks to the referee } \\
\text { group from the staff's point of view; } \\
\text { motivate staff participation }\end{array}$ & $\begin{array}{l}\text { Reflection on the project leader's } \\
\text { researcher role } \\
\text { Changes in practice ran parallel to } \\
\text { the research. }\end{array}$ \\
\hline $\begin{array}{l}\text { Kresheh \& } \\
\text { Barclay } \\
\text { (2007) } \\
\text { Jordan }\end{array}$ & $\begin{array}{l}\text { Action research to implement a } \\
\text { shared clinical record within } \\
\text { three hospitals }\end{array}$ & $\begin{array}{l}\text { To describe the practice- } \\
\text { research engagement that } \\
\text { occurred during an action } \\
\text { research project }\end{array}$ & $\begin{array}{l}\text { Midwives } \\
\text { Nurses (n=NR) } \\
\text { (and doctors) }\end{array}$ & Preparation, Execution, Translation & Benefits and challenges \\
\hline
\end{tabular}




\begin{tabular}{|c|c|c|c|c|c|}
\hline & & & & $\begin{array}{l}\text { Planning, design, study intervention, } \\
\text { implementation (of a new clinical } \\
\text { record) }\end{array}$ & \\
\hline $\begin{array}{l}\text { Poat et al. } \\
\text { (2003) } \\
\text { United } \\
\text { Kingdom }\end{array}$ & $\begin{array}{l}\text { Randomised Controlled Trial to } \\
\text { investigate whether routine } \\
\text { suturing of perineal lacerations is } \\
\text { required }\end{array}$ & $\begin{array}{l}\text { To report reflections by } \\
\text { researcher on the effect of } \\
\text { midwives' attitude on the } \\
\text { research process }\end{array}$ & Midwives (n=NR) & $\begin{array}{l}\text { Execution } \\
\text { Clinical midwives acted as recruiters } \\
\text { of the women, randomised } \\
\text { consenting women who fitted } \\
\text { inclusion criteria }\end{array}$ & $\begin{array}{l}\text { Researchers observations on how } \\
\text { attitudes of midwives as recruiters } \\
\text { can negatively affect the research } \\
\text { process }\end{array}$ \\
\hline $\begin{array}{l}\text { Reed \& } \\
\text { Hocking } \\
\text { (2013) } \\
\text { New Zealand }\end{array}$ & $\begin{array}{l}\text { Action research to identify } \\
\text { strategies senior occupational } \\
\text { therapists adopt to disseminate } \\
\text { new concepts that have the } \\
\text { potential to revise and transform } \\
\text { practice }\end{array}$ & $\begin{array}{l}\text { To reporting the study } \\
\text { Reflections by occupational } \\
\text { therapists on their involvement }\end{array}$ & $\begin{array}{l}\text { Occupational } \\
\text { Therapists }(n=6)\end{array}$ & $\begin{array}{l}\text { Preparation, Execution, Translation } \\
\text { Co-researchers }\end{array}$ & $\begin{array}{l}\text { Practitioners descriptions and } \\
\text { reflections on process and } \\
\text { transformations in practice } \\
\text { One practice story which illustrated } \\
\text { the impact involvement had on } \\
\text { practice }\end{array}$ \\
\hline $\begin{array}{l}\text { Renfrew et al. } \\
(2008) \\
\text { United } \\
\text { Kingdom }\end{array}$ & $\begin{array}{l}\text { Development of evidence-based } \\
\text { recommendations to promote and } \\
\text { support breast feeding }\end{array}$ & $\begin{array}{l}\text { To test a structured process of } \\
\text { developing evidence-based } \\
\text { recommendations } \\
\text { in public health while } \\
\text { involving a broad constituency } \\
\text { of } \\
\text { practitioners, service } \\
\text { commissioners and service } \\
\text { user representatives }\end{array}$ & $\begin{array}{l}\text { Stage 1: Consultation } \\
\text { on evidence-based } \\
\text { recommendations for } \\
\text { practice via electronic } \\
\text { survey } \\
\text { Midwives (n=212) } \\
\text { (and nurses, health } \\
\text { visitors, Sure Start } \\
\text { workers, social } \\
\text { services, dietician, } \\
\text { GP) } \\
\text { Service users } \\
\text { Service } \\
\text { commissioners } \\
\text { Stage 2: Analytical } \\
\text { consultation } \\
\text { workshops } \\
\text { Midwives, } \\
\text { Health visitors, Sure } \\
\text { Start workers and } \\
\text { breastfeeding }\end{array}$ & $\begin{array}{l}\text { Translation } \\
\text { Consultation to ensure that the final } \\
\text { recommendations reflected a critical } \\
\text { balance between the scientific } \\
\text { confidence in the findings, and a } \\
\text { realistic and practical appreciation of } \\
\text { what would really work in practice } \\
\text { Implementation (of evidence-based } \\
\text { recommendations for practice) }\end{array}$ & $\begin{array}{l}\text { Researcher perception of positive } \\
\text { experience and outcomes } \\
\text { Methodological challenges of } \\
\text { involving stakeholders }\end{array}$ \\
\hline
\end{tabular}




\begin{tabular}{|c|c|c|c|c|c|}
\hline & & & $\begin{array}{l}\text { Counsellors, senior } \\
\text { executive level in } \\
\text { NHS Trusts, national } \\
\text { policy leads } \\
(\mathrm{N}=\mathrm{NR})\end{array}$ & & \\
\hline $\begin{array}{l}\text { Roll et al. } \\
2013\end{array}$ & $\begin{array}{l}\text { Multisite, randomized, } \\
\text { behavioural clinical trial of a } \\
\text { music therapy intervention for } \\
\text { adolescents/young adults (AYA) } \\
\text { undergoing stem cell transplant } \\
\text { for an oncology condition Stories } \\
\text { and Music for Adolescent/Young } \\
\text { Adult Resilience during } \\
\text { Transplant (SMART) }\end{array}$ & $\begin{array}{l}\text { To describe the efforts of the } \\
\text { core research team to engage } \\
\text { and include direct care nurses } \\
\text { at each study site in the } \\
\text { conduct of the study. }\end{array}$ & & $\begin{array}{l}\text { Execution } \\
\text { Informing study staff of patient } \\
\text { clinical status; (b)organizing nursing } \\
\text { care and symptom management to } \\
\text { maximize ability of study } \\
\text { participation to complete study } \\
\text { activities; (c) supporting and } \\
\text { encouraging patient participation; } \\
\text { and (d) following quality assurance } \\
\text { procedures to maintain evaluator } \\
\text { blinding during the intervention. }\end{array}$ & $\begin{array}{l}\text { Researchers description of the } \\
\text { challenges experienced and } \\
\text { strategies put in place to address } \\
\text { challenges }\end{array}$ \\
\hline $\begin{array}{l}\text { Sadler et al. } \\
\text { (2017) } \\
\text { United } \\
\text { Kingdom }\end{array}$ & $\begin{array}{l}\text { To select an intervention to } \\
\text { improve long term care for stroke } \\
\text { survivors with multi-morbidity }\end{array}$ & $\begin{array}{l}\text { Describes a stakeholder } \\
\text { engagement study design } \\
\text { informed by co-production } \\
\text { principles in which } \\
\text { stakeholders prioritised ways } \\
\text { in which data, or information } \\
\text { could support improvements in } \\
\text { long-term care for stroke } \\
\text { survivors with multi-morbidity }\end{array}$ & $\begin{array}{l}\text { Occupational } \\
\text { Therapist }(\mathrm{n}=1) \\
\text { Physiotherapist }(\mathrm{n}=2) \\
\text { Speech and Language } \\
\text { Therapist } \\
\text { Nurse ( } \mathrm{n}=2 \text { ) } \\
\\
\text { (and GPs, policy } \\
\text { makers, carers, } \\
\text { service users) }\end{array}$ & $\begin{array}{l}\text { Translation } \\
\text { Implementation (identify and } \\
\text { prioritise novel interventions } \\
\text { that utilise clinical and research data) }\end{array}$ & $\begin{array}{l}\text { Description of process } \\
\text { Brief discussion of strengths and } \\
\text { limitations }\end{array}$ \\
\hline
\end{tabular}

